Discussion Paper No. 10-102

\title{
The Influence of International Dispersed vs. Home-based R\&D on Innovation Performance
}

Bettina Peters and Anja Schmiele

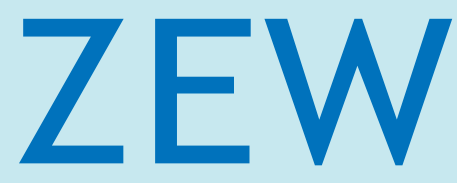

Zentrum für Europäische Wirtschaftsforschung $\mathrm{GmbH}$

Centre for European

Economic Research 
Discussion Paper No. 10-102

\title{
The Influence of International Dispersed vs. Home-based R\&D on Innovation Performance
}

\author{
Bettina Peters and Anja Schmiele
}

Download this ZEW Discussion Paper from our ftp server:

ftp://ftp.zew.de/pub/zew-docs/dp/dp10102.pdf

Die Discussion Papers dienen einer möglichst schnellen Verbreitung von neueren Forschungsarbeiten des ZEW. Die Beiträge liegen in alleiniger Verantwortung der Autoren und stellen nicht notwendigerweise die Meinung des ZEW dar.

Discussion Papers are intended to make results of ZEW research promptly available to other economists in order to encourage discussion and suggestions for revisions. The authors are solely responsible for the contents which do not necessarily represent the opinion of the ZEW. 


\section{Non-technical Summary}

The recent decade has shown a surge of firms globalising their innovation activities. This means that these firms have enlarged the number of countries where they perform $R \& D$ projects. Hence, for more and more firms R\&D is no longer a purely domestic activity. A major motive underlying the decision to shift corporate R\&D activities abroad is that firms seek to increase their chances to participate in international knowledge sharing. Absorbing knowledge from abroad is aimed at enhancing firms' innovativeness and consequently their competitiveness.

This paper aims at analysing whether a firm's innovation performance is enhanced by globalised $R \& D$. In order to evaluate the benefits of a strategy that disperses R\&D across foreign countries, we compare firms which have globalised their R\&D activities with firms performing $R \& D$ only in their home country and with firms that are engaged in no $R \& D$ activities at all. One main novelty of our research is that we furthermore distinguish between different degrees of $\mathrm{R} \& \mathrm{D}$ internationalisation, that is, the number of foreign countries in which a firm has R\&D laboratories. This allows us to shed light on the two competing hypotheses by Malecki (1980) and Von Hippel (1988) whether stronger dispersed international R\&D activities hamper or stimulate firms' innovation. Compared to previous research that is based on patents, we use two different well-established innovation output indicators to shed light on the effects of domestic and foreign R\&D: first, the introduction of new products and second their market success which is measured as the sales growth rate due to these innovations. We additionally examine whether the effects of international R\&D vary with different degrees of product novelty (firm and market novelties).

The study is based on a large data set of about 2100 firms surveyed in the Mannheim Innovation Panel (MIP). The MIP represents the German part of the European-wide harmonised Community Innovation Surveys (CIS).

Based on econometric analyses, we confirm that firms with both domestic R\&D and foreign $R \& D$ activities are more likely to launch new products than firms with home-based R\&D only or non-R\&D performers. This can be observed for both kinds of product innovations: market novelties and firm novelties. Regarding the innovation success, however, the results are not as clear-cut. Given the introduction of a firm novelty, firms with international R\&D centres are also more successful than non-R\&D performers and tend to be more successful than firms conducting solely domestic R\&D. On the contrary, the findings reveal that the location of 
R\&D does not matter for the success of market novelties once the market novelty has been launched to the market.

By comparing different degrees of $R \& D$ internationalisation, the study points out that firms with medium decentralised foreign $R \& D$ activities (in 2-3 countries) have a significantly higher likelihood to develop both market and firm novelties compared to firms with centralised foreign $R \& D$ in only one foreign subsidiary. A more decentralised foreign $R \& D$ organization does not exert an additional stimulating effect on the propensity to develop market novelties. On the other hand, it further increases the likelihood to develop firm novelties.

The results further elucidates that firms with medium decentralised $R \& D$ abroad achieve a higher sales growth with new products than firms which conduct R\&D at home only or than firms with highly decentralised foreign $R \& D$ activities. Again, the higher sales growth rates are mainly driven by firm novelties, not by market novelties. That is, given the introduction of a market novelty, the degree of decentralisation of international R\&D activities does not play a role for innovation success.

Finally, another salient finding that originates from this analysis is that German firms that have expanded their R\&D only to one foreign country do not outperform firms with domestic R\&D. 


\section{Das Wichtigste in Kürze}

Mit dem Ziel ihre Innovationskraft und ihre Wettbewerbsfähigkeit zu steigern, haben Unternehmen in den letzten Jahren zunehmend ihre Forschungs- und Entwicklungstätigkeiten (FuE) internationalisiert.

Diese Studie untersucht, ob und inwiefern internationale FuE-Tätigkeiten tatsächlich zu einer besseren Innovationsleistung der Unternehmen führen. Um die Strategie der Internationalisierung von FuE-Aktivitäten zu beurteilen, wird die Innovationsperformance von Unternehmen, die sowohl national als auch international FuE-Projekte durchführen verglichen mit denjenigen, die nur in ihrem Heimatland FuE tätigen und mit denjenigen, die keinerlei FuE-Tätigkeiten aufweisen. Unsere Studie unterscheidet sich von der bisherigen Forschung insbesondere in zwei Aspekten: Erstens unterscheiden wir Unternehmen nach dem Grad der Internationalisierung ihrer ausländischen FuE-Tätigkeiten. Dies erlaubt uns die Hypothese $\mathrm{zu}$ untersuchen, ob eine zunehmende Dezentralisierung von FuE den Innovationserfolg auf Grund des besseren Zugangs zu Wissensquellen erhöht oder auf Grund der zunehmenden Koordinierungskosten beeinträchtigt. Zweitens nutzen wir nicht wie bisherige Studien Patente als Erfolgsindikator, sondern evaluieren die Ergebnisse dieser unterschiedlichen Innovationsstrategien an Hand zweier marktbasierter Indikatoren. Dabei handelt es sich zum einen um die Einführung neuer Produkte und zum anderen um das Umsatzwachstum, das durch neue Produkte generiert wird. Bei neuen Produkten wird jeweils nach dem Grad der Neuigkeit unterschieden zwischen neuen Firmen- und Marktneuheiten.

Die Studie basiert auf den Daten von ca. 2100 Unternehmen, die im Rahmen des Mannheimer Innovationspanels (MIP) erhoben wurden. Das MIP stellt den deutschen Beitrag der europaweit harmonisierten Innovationserhebungen (CIS) dar.

Die Ergebnisse der ökonometrischen Analyse zeigen, dass Unternehmen, die sowohl im Inals auch im Ausland FuE betreiben, eine größere Wahrscheinlichkeit haben neue Produkte einzuführen als Unternehmen, die nur in Deutschland FuE betreiben oder die gar keine FuE durchführen. Dies gilt sowohl für Produkte, die neu für den Markt insgesamt sind als auch für solche, die nur eine Neuigkeit für das Unternehmen darstellen. Die Ergebnisse bezüglich des Innovationserfolgs sind dagegen nicht eindeutig. Unter der Voraussetzung, dass ein Unternehmen eine Firmenneuheit eingeführt hat, weisen Unternehmen mit internationaler FuE-Aktivität auch ein höheres Umsatzwachstum mit diesen neuen Produkten auf als andere Unternehmen. Das gleiche Erfolgsmuster lässt sich jedoch für Marktneuheiten nicht beobachten. Wenn es einem Unternehmen gelungen ist, eine Marktneuheit einzuführen, dann 
spielt der Ort, wo diese Marktneuheit entwickelt wurde, letztlich keine Rolle für den Innovationserfolg mit diesen Produkten.

Differenziert man nach dem Grad der Internationalisierung, dann zeigt sich, dass Unternehmen mit ausländischen FuE-Standorten in einer moderaten Anzahl an Ländern (2-3 Länder) eine signifikant höhere Wahrscheinlichkeit haben, Markt- und Firmenneuheiten einzuführen als Unternehmen, die nur in einem ausländischen Standort FuE-Aktivitäten betreiben. Eine darüber hinaus gehende Dezentralisierung der FuE-Aktivitäten wirkt zwar noch positiv auf die Einführung von Firmenneuheiten, hat jedoch keinen zusätzlich stimulierenden Effekt auf die Einführung von Marktneuheiten.

Die Ergebnisse zeigen darüber hinaus, dass Unternehmen mit einem mittleren Internationalisierungsgrad ein signifikant höheres Umsatzwachstum mit neuen Produkten erzielen. Dieses lässt sich erneut auf Firmen-, aber nicht auf Marktneuheiten zurückführen. D.h. gegeben die Einführung einer Marktneuheit, spielt der Grad der FuEInternationalisierung des Unternehmens, keine Rolle für den Innovationserfolg.

Ein weiteres markantes Ergebnis dieser Studie ist, dass Unternehmen, die ihre ausländischen FuE-Aktivitäten bislang auf ein Land konzentriert haben, keine signifikant bessere Innovationsperformance aufweisen als Untenehmen, die nur im Inland FuE durchführen. 


\title{
The Influence of International Dispersed vs. Home- based R\&D on Innovation Performance
}

\author{
Bettina Peters ${ }^{\text {a,b }}$ and Anja Schmiele ${ }^{\text {a,c }}$ \\ ${ }^{\text {a }}$ ZEW - Centre for European Economic Research, Mannheim \\ ${ }^{\mathrm{b}}$ Zurich University \\ ${ }^{c}$ WHU - Otto Beisheim School of Management
}

December 2010

\begin{abstract}
Recent years have shown a surge of firms globalising their innovation activities in order to gain from international knowledge. This paper evaluates this strategy by investigating whether firms with international $R \& D$ are more innovative than firms doing $R \& D$ only in their home country. One main novelty is that we shed light on two competing hypotheses whether stronger dispersed international R\&D activities hamper or stimulate innovation. Second, we employ two well-established market-based indicators for innovation (introduction of and sales growth rates due to new products) instead of looking at inventions (patents). Using German CIS data for about 2100 firms, the econometric results show that firms with international $R \& D$ are more likely to launch new products (firm and market novelties) than firms with home-based R\&D only. They are also more successful in terms of higher sales growth with firm novelties. However, given the introduction of a market novelty, the location of R\&D doesn't matter for the sales growth with market novelties. The results concerning the degree of R\&D internationalisation are mixed: The likelihood of introducing firm novelties increases with a stronger dispersion of foreign R\&D activities (for market novelties only up to a specific point). The relationship between degree of $R \& D$ internationalisation and innovation success turns out to be inverse u-shaped.
\end{abstract}

Keywords: R\&D, Internationalisation, Innovation performance, Decentralisation

JEL-Codes: O32, F23

\section{Acknowledgements}

We are grateful to Georg Licht, Christian Rammer, Jürgen Weigand and participants at the INIR Workshop (Leuven, 2008), the Asigo Conference (Nuremberg, 2009), the Micro Evidence on Innovation and Development (MEIDE) Conference (Tartu, 2010), the International Industrial Organization Conference (Vancouver, 2010), the Annual Meeting of the Academy of International Business (AIB; Rio de Janeiro, 2010), the European Association for Research in Industrial Economics (EARIE) Conference (Istanbul, 2010) and seminars at ZEW (Mannheim, 2009) and WHU (Vallendar, 2010) for helpful comments and suggestions on previous versions. All remaining errors are ours. 


\section{Introduction}

Firms' competitiveness depends to a great extent on their innovativeness. Due to the increasing technological complexity of products and processes and the speeding up of technological progress, firms have to source knowledge outside their boundaries in order to complement internal knowledge. This includes the use of globally available resources to foster their innovation outcomes (Kotabe, 1990). In order to do so, firms may pursue different strategies. The two most prominent strategies are to cooperate with international partners or to establish own research and development (R\&D) laboratories abroad. Fascinatingly, the recent decade has shown that corporations increasingly globalise their R\&D and innovation activities by setting up own foreign R\&D departments (UNCTAD, 2005). This phenomenon can be observed for both large multinational firms (MNEs) and international SMEs. In Germany for instance, about 3\% of - mainly medium-sized - innovative firms without foreign R\&D activity in 2005 planned to start it in the subsequent two years 2006/2007 (Rammer and Schmiele, 2008).

The international business literature stresses that firms pursue two main motives by performing their R\&D activities abroad (Granstrand et al., 1993, Von Zedtwitz and Gassmann, 2002, Kuemmerle, 1997). On the one hand, firms want to adapt their existing technologies to local demand and manufacturing conditions (exploitation strategy). On the other hand, by setting up foreign R\&D subsidiaries firms seek to get access to local science and technology resources which enable them to absorb and integrate knowledge from abroad into their innovation process (home-base augmenting strategy). It has been emphasised that an effective innovation strategy needs to balance the exploitation of existing knowledge with non-local knowledge exploration (Levinthal and March, 1993). It has further been proven that putting existing pieces of knowledge together often leads to innovations (Grant, 1996; Arora and Gambardella, 1990; Cohen and Malerba, 2001). In this vein, the internationalisation of innovation activities may lead to the combination of existing knowledge from the firm's knowledge stock with foreign knowledge contributed by foreign local staff and spillovers from the firm's foreign business environment such as cooperating firms, competitors, customers, suppliers and scientific institutions. Given that knowledge spillovers are stronger within countries than across countries (Jaffe et al., 1993; Branstetter, 2001), firms that perform R\&D activities only in their home country are less likely to have access to foreign knowledge. Learning-by-exporting has been considered one alternative of how firms could 
benefit from foreign countries' expertise by engaging in local markets and interacting with customers (Clerides et al., 1998; Bernard and Jensen, 1999). However, it is pointed out that knowledge often cannot overcome national boundaries when it is not codified (implicitly) and embedded in routines and thus hard to transfer (Kogut, 1991; Kogut and Zander, 1992).

The potential knowledge gains from foreign $R \& D$ stand facing potential losses. They may arise due to intra-firm knowledge losses, intra-firm coordination costs of research or foregone economies of scale in conducting research. Despite the trend to internationalise $R \& D$, the empirical evidence about the effectiveness of foreign $R \& D$ in terms of innovation output is rather scarce and limited to patents. But patent-based indicators have been heavily criticised as being a rather poor yardstick for innovative output (see, e.g., Scherer, 1965; Griliches, 1990). In this paper we address the question whether international $R \& D$ is conducive to a firm's innovation performance.

Our research aims at extending the existing literature in three ways. First, we use two alternative well-established market-based innovation performance measures. We provide evidence of how potential gains from foreign $R \& D$ activities influence the introduction of new products ("innovation outcome") and whether firms with foreign R\&D achieve a higher sales growth with innovative products ("innovation success"). Product innovations can be either new to the firm only (firm novelty) or to the market as a whole (market novelty), i.e. they greatly vary according to their degree of novelty. We suppose that foreign R\&D is more crucial for developing market novelties and thus secondly examine whether the effects vary with the degree of product novelty. Since firms are expanding their number of international research locations, we finally investigate the effect of a greater decentralisation of foreign $R \& D$ locations on firms' innovation performance.

To answer our research question, we estimate knowledge production functions (Pakes and Griliches, 1984) by employing the two-step selection model proposed by Heckman (1979). The empirical analysis draws upon a sample of about 2100 German firms collected within the Community Innovation Surveys (CIS). In contrast to previous studies that mainly compare the contribution of foreign and home-based $R \& D$ activities for firms with globalised $R \& D$ activities, our data set allows us to liken firms with globalised $R \& D$ to firms performing $R \& D$ only at their home country or doing no R\&D activities at all. The potential added value of foreign $R \& D$ to domestic $R \& D$ in comparison with only domestic $R \& D$ activities in terms of innovation performance is interesting both to scholars and managers.

To summarise our main results: We find that firms with both domestic and foreign $R \& D$ activities are more likely to launch new products (both firm and market novelties) than firms 
with home-based R\&D only. Given the introduction of a new product they do likewise achieve a significantly higher sales growth due to this innovation than firms with home-based R\&D only. This higher innovation success can be traced back to firm novelties. No differences in innovation success, however, could be found for market novelties. The degree of R\&D internationalisation has an inverse $\mathrm{u}$-shaped effect on both innovation performance measures. A moderate number of R\&D locations abroad exert the strongest influence on innovation outcome with new products, market and firm novelties. Further, sales growth due to product innovations and firm novelties also peaks with a moderate number of $R \& D$ locations abroad.

This paper continues in the following outline: section 2 presents related literature and relevant theoretical concepts which lead to the development of hypotheses. Section 3 explores the dataset and the empirical methods which are employed to test the hypotheses. Section 4 sets forth the results of the econometric analysis, and section 5 concludes with a discussion of the retrieved results and management recommendations.

\section{Internationalisation of R\&D Activities - What Do We Know so Far?}

\subsection{Potential Benefits of International R\&D}

Multinational Enterprises (MNE) are said to be an important driver of globalization by increasing the interdependency and relatedness of geographically dispersed actors (Archibugi and Immarino, 2002). The internationalisation of internal R\&D activities has followed the internationalisation of production and other market-related business processes. Though R\&D still shows the least degree of internationalisation of all business processes, it is an increasing phenomenon (see UNCTAD, 2005). The UNCTAD (2005) report shows that about $40 \%$ of the Western European firms have international R\&D expenditures in comparison to $24 \%$ of the North American MNEs and 15\% of the Japanese multinationals. The industries which show the highest degree of international R\&D spending are chemicals, pharmaceuticals, electronics and automotive.

The motivations of firms to internationalise their R\&D have been distinguished into market seeking, technology seeking and efficiency seeking purposes. However, it is unlikely that firms are driven only by one but rather by all three motivations (DeMeyer, 1993). Furthermore, the objectives of R\&D labs abroad have been changing over time towards 
knowledge sourcing and development tasks (Frost, 2001; Hakanson and Nobel, 1993; Wortmann, 1990). The internationalisation of R\&D enables firms to both widen and deepen their technological scope (Pearce and Papanastassiou, 1996) due to improved technical learning which is fostered by international R\&D activities (DeMeyer, 1993).

The resourced-based theory of the firm provides a framework to explain the differences in firms' strategic decisions, performance and competitive advantage (Grant, 1996; Liebeskind, 1996) Firms are seen as bundles of resources and capabilities that act as knowledgeintegrating institutions and develop and deploy the resource base (Grant, 1996). Firms with superior resources will generate rents (Peteraf, 1993). The knowledge-based view which has evolved from the resource-based theory emphasises knowledge as one of the most valuable resources. The sourcing of global knowledge would allow firms to gather additional and distinct knowledge relative to rivals and inhibits the chance to build an idiosyncratic knowledge base which can become a competitive advantage (Peteraf, 1993). This mind-set leads to the assumption that numerous pools of knowledge are more beneficial to a firm's innovativeness than a few sources. For developing new products, however, it is ultimately essential to apply the knowledge which creates a competitive advantage in case of a successful innovation (Liebeskind, 1996; Grant, 1996). The knowledge-based view of the firm thus implies that the foreign knowledge will increase firms' innovativeness and market success with innovations when they possess abilities necessary to utilise their knowledge base. In this regard, the corporate knowledge base also provides the foundation to decide which and how knowledge is applied in actual and future periods (Ndofor and Levitas, 2004).

\subsection{Moderating Factors of Firms' Benefits of International R\&D}

The potential benefits of international $R \& D$ activities are moderated by a number of factors that can hamper the outcome of international research activities. The improvement of innovation performance can only be as strong as the international R\&D performing firms realise and use the chances of these ventures. Thus, it is important for firms to pursue an appropriate strategy to capture the resources abroad which are beneficial to them and to avoid losses.

First, the roles and tasks which are assigned to the innovating subsidiaries abroad affect their importance for the firms' innovation output (Iwasa and Odagiri, 2004). The mandates of subsidiaries abroad differ by their level of $R \& D$ orientation and their focus on production support. Some R\&D labs abroad have the task to absorb new knowledge and to develop new products. They act as 'knowledge augmenting' units (Kuemmerle, 1997) or 'global creators' (Nobel and Birkinshaw, 1998). Other R\&D centres abroad are characterised as 'local or 
global adaptors' (Nobel and Birkinshaw, 1998), 'home base exploiting' (Kuemmerle, 1997) units or 'support laboratories' (Pearce, 1989). Their work description comprises the support of local production, the assimilation of market knowledge and the application to customers' satisfaction (Pearce and Papanastassiou, 1996). According to their different mandates, R\&D centres abroad are likely to generate distinct degrees of quality and quantity of knowledge and skills. While some subsidiaries can contribute to the development of new products, the adaptation of existing products is aimed at enhancing the sales of innovative products on foreign markets.

The type of $R \& D$ and as a result the degree of novelty of the innovation output is also determined by the international $R \& D$ organization (Chiesa, 1996), in particular by the degree of decentralisation. A centralised $\mathrm{R} \& \mathrm{D}$ organization conducts all the necessary work to develop new products in one location (Malecki, 1980) which is mostly in the firm's home country. In decentralised R\&D structures, research is carried out within divisions or business units (Argyres and Silverman, 2004). The role of decentralisation for innovation performance is ambiguous. Some scholars have argued that centralization of R\&D facilities is the better R\&D organization for research purposes since economies of scale and scope can be realised (Malecki, 1980; Von Zedtwitz et al., 2004). The international decentralisation of a firm's R\&D organization demands not only the management of corporate innovation efforts between the headquarter and subsidiaries but also across country borders. This involves the risk that knowledge is getting lost when it is transferred between R\&D units (Szulanski 1996) or that innovation projects are duplicated in different R\&D units (Gassman and Von Zedtwitz 1999). The increase in transactions due to the internationalisation is likely to drive the costs as proposed by the transaction cost theory (Coase, 1937; Williamson, 1985). Opponents argue that $R \& D$ decentralisation reduces managerial opportunism at a single $R \& D$ centre and empowers divisions which are closer to markets and specific demands (Von Hippel, 1988; Williamson, 1985).

Another linchpin is the degree of international R\&D decentralisation and the way of transferring and integrating international subsidiary knowledge into the corporate innovation process. The management and integration of international $R \& D$ centres are an important topic in the international business literature (Gassmann and Von Zedtwitz, 1999; Von Zedtwitz et al., 2004; Edler et al., 2002; Hemmert, 2003/04). It has been argued that the usage of the potential global know-how does not depend on the presence of R\&D labs in many parts of the world per se but more importantly on the internal firm mechanisms to integrate knowledge across R\&D organizations (Singh, 2008). Leveraging the capabilities and resources of 
subsidiaries across divisions and locations has been put forward to be essential for the global success of firms (Bartlett and Ghoshal, 1989; Birkinshaw et al., 1998; Frost et al., 2002; Nobel and Birkinshaw, 1998). In our research framework, special attention has to be paid to knowledge flows within MNEs. The integration of the foreign R\&D labs is on the one hand fostered by personnel contacts and exchanges between home and overseas R\&D centres. It is likewise important for the transfer of locally developed knowledge to the domestic headquarter (Hakanson and Nobel, 2001; Björkmann et al., 2004). On the other hand, the integration of the outcomes of $R \& D$ performed abroad requires a certain stage of $R \& D$ activeness of the recipient firm in the home country. Firms should carry out R\&D continuously to keep up with technological developments (Tilton, 1971) and hereby develop their ability to identify and absorb new information from overseas R\&D subsidiaries (Cohen and Levinthal, 1989, 1990). These so-called absorptive capabilities of the receiving firm stimulate knowledge flows (Minbaeva et al, 2003) or act as a barrier to MNEs' knowledge flows if they lack these capabilities (Szulanski, 1996).

A firm that sources knowledge from the host country is most likely to benefit from these activities if the foreign knowledge complements existing knowledge in its R\&D labs in the home country. The complementarity concept generally means that one activity pays off more if the other activity is also carried out (Milgrom and Roberts, 1995; Schmiedeberg, 2008). Therefore, domestic and foreign $R \& D$ act as complements if conducted together they increase the innovation performance more than one R\&D activity alone. A variety of complementarities in $R \& D$ activities have been proved to positively influence innovation success: Internal $\mathrm{R} \& \mathrm{D}$ has been found to be complementary to contracted $\mathrm{R} \& \mathrm{D}$ (Schmiedeberg, 2008), external technology acquisition (Cassiman and Veugelers, 2006) and R\&D cooperation for different industries and partners (Schmiedeberg, 2008; Cassiman and Veugelers, 2002, 2005; Schmidt, 2005; Arora and Gambardella, 1990). Some of the advantages apply only to truly external firm innovation partners such as risk and cost sharing (Love and Roper, 2004) and do not count for international corporate research centres. Notwithstanding, domestic and foreign R\&D may generate synergy effects since different locations may imply access to additional sources of knowledge.

\subsection{The Innovation Output of Firms with International R\&D}

The existing literature provides only scarce evidence whether international R\&D is beneficial to firms' innovation performance. Existing studies can be distinguished whether they focus on the innovative performance of foreign $R \& D$ subsidiaries or on the effect on innovations developed by the headquarter. The to-date studies mostly use patent data to analyze the 
impact of foreign knowledge sources on firms' innovations. Following this strategy, Iwasa and Odagiri (2004) have examined the contribution of R\&D abroad on the firms' invention activity at home and abroad for a sample of 137 Japanese MNEs. They find that innovative (not adaptive) R\&D which is carried out abroad in the US and EU exert a positive impact on the number of a firm's inventions in Japan, as measured by the number of granted patents. Their results thus confirm the technology sourcing activities of subsidiaries abroad. Using a panel study of 65 Japanese pharmaceutical firms, Penner-Hahn and Shaver (2005) have examined the role of foreign $R \& D$ on the number of patents as performance measure. They confirm that international $R \& D$ activities exert a positive effect on patenting. Phene and Almeida (2008) have investigated the determinants of subsidiary innovation. They provide evidence that knowledge from host country firms positively affects scale (number of patents) and quality (number of citation received) of subsidiary innovation. On the contrary, knowledge assimilated from MNE headquarters and other subsidiaries play no significant role for subsidiary innovation. Frost (2001) studied the geographic sources of foreign subsidiaries' innovation. He distinguishes firms' innovation activities abroad into the exploitation of existing firm knowledge and exploring local knowledge sources abroad. His findings suggest that foreign subsidiaries' patents rather cite knowledge sources from those locations that possess the strongest expertise and technological advantage. Foreign subsidiaries' patents are therefore likely to be based on host country knowledge when it is technological advanced in that relevant field and if the foreign subsidiary is of larger scale.

Despite the controversial discussion about the effect of an increasing degree of international R\&D decentralisation, the international business literature still lacks empirical evidence. So far, the impact of R\&D organization on innovative outcome has been analysed for the number of national R\&D locations within Finland (Leiponen and Helfat, 2010) and the US (Argyres and Silverman, 2004). Leiponen and Helfat (2010) find that R\&D decentralisation fosters the extent and positive impact (e.g. reduction of costs, opening of new markets, fulfilling standard or regulations) of innovation outcomes. Argyres and Silverman (2004) explore the link between firms' R\&D organization and the importance of innovations produced for a small sample of 71 US firms. To measure the importance of innovations, they employed distinct indicators based on patent citations. In contrast to Leiponen and Helfat (2010), their findings suggest that firms with centralised R\&D organizations generate innovations with greater technological impact (number of citations) and they impact upon a broader range of technological areas. However, the effect was found to be non-linear. That is, firms with strongly decentralised $R \& D$ exhibit a greater innovation impact than firms with slightly decentralised R\&D. In a related study, Singh (2008) has evaluated the effect of 
geographically dispersed - but not necessarily international - R\&D activities on the quality of innovation performance. ${ }^{1}$ Employing the number of patent citations as performance indicator he finds on average a significantly negative influence of the geographic spread of R\&D activities on the innovation value. This result indicates that potential gains from access to diverse knowledge from different locations are offset by difficulties in managing and integrating knowledge across dispersed R\&D units. Firms pursuing cross-regional knowledge integration strategies ${ }^{2}$ benefit more from dispersed $R \& D$ though the overall effect remains negative. Notwithstanding, there is no evidence so far whether these results also hold for international $R \& D$ decentralisation and our research is aimed at filling this gap.

Furthermore, all above-mentioned studies are based on patent data. As it has been argued before, patents might not always be the appropriate way to capture the innovation success of R\&D activities. Patents prove the result of inventive activities and display the location of inventors. However, not all patented inventions result in innovations and not all inventions and innovations are patented (Griliches, 1990; Jaffe and Trajtenberg, 2002). Therefore, patents cover only a threshold of the results from innovation activities abroad (Levin et al., 1987; Arundel and Kabla, 1998). Some underlying reasons are time and costs which are involved in the patent application process, as well as the aspect of knowledge disclosure by patents and the fact that only new inventions can be patented, innovations new to the firm are not patentable. In a recent study on a related topic, Criscuolo et al. (2010) have employed both patent data and firm level innovation data to investigate the effect of global engagement on innovation performance. They find that globally engaged firms (per definition multinational parent firms and multinational affiliates) applied for more patents, have a higher likelihood of introducing innovations and achieve a higher share of sales with innovations. These results add a more international perspective to the existing innovation performance literature. However, this study merely analyses how firm status, measured by indicator variables for a multinational parent, a multinational affiliate, a local exporting firm and a local non-exporting firm, affects innovation performance. The effect of both domestic and foreign research and development activities on innovation performance remains unobserved. Therefore our paper aims to contribute firm-level evidence about international R\&D activities and their effect on innovation outcome and innovation success.

\footnotetext{
${ }^{1}$ The spread is measured as the average geographic distance between the address of the first investors in any two patent pairs of the firm.

2 Cross-regional knowledge integration is measured along three dimensions: inventors with regional ties, regional mobility of inventors and knowledge sourcing from other locations within the firm.
} 


\subsection{Hypotheses}

In order to investigate the relationship between international $R \& D$ activities and innovation performance, we test six hypotheses. Following the rationale of the knowledge-based view, a larger number of $R \& D$ locations give firms the opportunity to interact with a greater number of international actors and a wider range of knowledge sources. Accordingly, firms' international $R \& D$ activities represent an advantage by having multiple contacts with foreign knowledge sources. The access to a larger knowledge pool should result in a better innovation outcome (H1) and innovation success (H2):

H1: Firms with international $R \& D$ activities are more innovative than firms that undertake $R \& D$ solely in their home country.

H2: Firms with international $R \& D$ activities achieve a higher innovation success than firms that only have domestic $R \& D$ capacities.

Section 2.2 has elaborated on some moderating factors that affect benefits. The second set of hypotheses is devoted to the role of the degree of $R \& D$ internationalisation and its impact on innovation. The literature provides two competing hypotheses how the degree of internationalisation of $\mathrm{R} \& \mathrm{D}$ dispersion may affect innovation outcome and innovation success. Therefore we define hypotheses $\mathrm{H} 3 \mathrm{a}$ and $\mathrm{H} 4 \mathrm{a}$ based on the arguments stemming from the knowledge-based view and the expected positive effects of a decentralised R\&D organisation raised by Von Hippel (1988):

H3a: The degree of $R \& D$ internationalisation has a positive influence on the likelihood of introducing innovations (innovation outcome).

H4a: The degree of R\&D internationalisation has a positive influence on firms' innovation success.

Following the line of reasoning that increased international $R \& D$ decentralisation implies the loss of economies of scale and scope, the higher likelihood of redundant innovation projects and higher transaction costs, we formulate hypotheses $\mathrm{H} 3 \mathrm{~b}$ and $\mathrm{H} 4 \mathrm{~b}$ which state that these costs outweigh the gains due to better access to foreign knowledge:

H3b: The degree of $R \& D$ internationalisation has a negative influence on the likelihood of introducing innovations (innovation outcome).

H4b: The degree of $R \& D$ internationalisation has a negative influence on firms' innovation success.

A rejection of hypothesis $\mathrm{H} 3 \mathrm{a}$ would lead to the conclusion that the costs outweigh the benefits of international R\&D activities and thus speak in favour of hypothesis H3b. Due to 
lack of data and similar to Singh (2008), we cannot test hypotheses about the other moderating factors, i.e. about the effect of subsidiaries' mandates and internal organisational mechanisms to transfer knowledge across different R\&D units within the firm efficiently. Instead we will draw indirect inference on these matters based on our results.

\section{Empirical Analysis}

\subsection{Data Set}

To test our hypotheses, we employ data from the Mannheim Innovation Panel (MIP). The MIP is an annual innovation survey conducted by the Centre for European Economic Research (ZEW), the Fraunhofer Institute for Systems and Innovation Research (ISI) and the Institute for Applied Social Sciences (infas) on behalf of the German Federal Ministry of Education and Research (BMBF). The survey methodology and definitions of innovation indicators are based on the Oslo Manual (see OECD and Eurostat 2005), thereby yielding internationally comparable data on innovation activities of German enterprises. The MIP is the German contribution to the Europe-wide harmonised Community Innovation Surveys (CIS) which take place every 4 year and since 2005 every second year. The MIP survey targets legally independent firms with headquarters located in Germany and with at least five employees in manufacturing, mining, energy and in selected service sectors. The survey is drawn as a stratified random sample and is representative of the corresponding target population.

The CIS provides rich information on firms' innovation behavior such as the introduction of product and process innovation, innovation expenditure, $R \& D$ engagement, share of sales with new products, information sources, hampering factors and general firm information such as sales, employment, exports, type of ownership and so on. The data has increasingly been exploited in empirical research to study a variety of innovation-related questions (see e.g. Cassiman and Veugelers, 2006; Criscuolo et al., 2010 and the survey by Mairesse and Mohnen, 2010). Usually, the MIP goes beyond the extent of the core CIS surveys and poses additional questions on innovation-related topics. The 2006 survey additionally collects data about foreign innovation activities. Firms were asked whether they conduct foreign innovation activities in 2005 and if so what kind of activity they perform abroad (R\&D, implementation of new processes, conception/design/construction of new products, manufacturing of new products or merely sales of new products). For each type of activity 
firms were furthermore requested to state in a free text field in which countries they predominantly perform them.

Its design as a panel data set presents a main virtue of the MIP. Unfortunately, information on international R\&D activities is only available in one wave. However, by merging different waves, the panel structure allows us to analyze the effect of R\&D activities abroad on future innovation performance. More precisely, we merge the 2006 survey with the latest available 2009 survey. This creates a time lag of 3 years between existing corporate R\&D activities abroad in 2005 (2006 survey) and the measurement of innovation performance in the period 2006-2008 (2009 survey). Since empirical evidence has pointed towards the fact that firms tend to carry out rather applied $R \& D$ at foreign locations, the observed time lag of up to three years between innovation efforts and observed performance seems to be adequate. Moreover, this approach reduces potential endogeneity problems between the location of R\&D activities and innovation output which usually arise in cross-sectional analyses. Endogeneity might occur because the most innovative firms may have the prerequisites to perform R\&D abroad, i.e. self-select into the sample of international R\&D performing firms.

The samples in 2006 and 2009 consist of 5187 and 7662 firms, respectively. Though the surveys are designed as a panel, merging the two cross-sections leads to a reduction of about $50 \%$ in the amount of observations since participation is voluntary. For estimation purposes we further exclude firms with incomplete data for any of the relevant variables. 2118 firms remain for the empirical analysis.

\subsection{Dependent Variables}

We define two sets of dependent variables, following the approach many other studies have used to analyse the effect of firms' national R\&D activities on innovation success (see e.g. Griffith et al., 2006; Parisi et al., 2006). That is, we first investigate whether a firm has introduced new products in the period 2006 to 2008. According to the Oslo Manual, these new products could be either new to the market (market novelties) or new to the firm only (firm novelties), i.e. they greatly differ in their degree of novelty. We suppose that foreign R\&D is more crucial for developing market novelties. Thus, we additionally differentiate between two binary variables, namely market novelties and firm novelties.

Given that the firm has introduced a product innovation, market and firm novelty, respectively, we investigate the market success with these innovation outcomes in a similar manner as it has been done by a variety of studies before (Criscuolo and Haskel, 2003; Mairesse and Mohnen, 2005; Jefferson et al., 2006). In contrast to these studies that define innovation success by the share of sales in a given year due to innovations in the prior three 
years, we employ a dynamic success measure that accounts for sales changes as proposed by Harrison et al. (2008). Innovation success is measured by the sales growth rate between the years 2006 and 2008 due to new products, market novelties and firm novelties introduced in this period of time, respectively. It is computed as the share of sales due to new products in 2008 times sales in 2008 divided by sales in 2006. Table 1 summarizes the definition of the six dependent variables.

\section{Table 1: Definition of Dependent Variables}

\begin{tabular}{|c|c|}
\hline Dependent Variables & Definition \\
\hline Firms with product innovations & $\begin{array}{l}1 \text { if the firm has introduced product innovations in the period 2006-2008. } \\
\text { Product innovations are new or significantly improved products and/or } \\
\text { services with respect to technological characteristics or intended uses. } \\
\text { They could be either new to the market or to the firm only (market or } \\
\text { firm novelties). }\end{array}$ \\
\hline Firms with market novelties & $\begin{array}{l}1 \text { if the firm has launched market novelties in 2006-2008. Market } \\
\text { novelties are product innovations that a firm has introduced onto the } \\
\text { market prior to any competitor. }\end{array}$ \\
\hline Firms with firm novelties & $\begin{array}{l}1 \text { if the firm has introduced at least one product in } 2006-2008 \text { that has } \\
\text { been new to the enterprise but not to the market. }\end{array}$ \\
\hline Sales growth due to new products & $\begin{array}{l}\text { Growth rate of turnover between } 2006-2008 \text { due to new products in that } \\
\text { period; computed as: share of sales with new products * (sales in } 2008 \text { / } \\
\text { sales in 2006) }\end{array}$ \\
\hline Sales growth due to market novelties & $\begin{array}{l}\text { Growth rate of turnover between } 2006-2008 \text { due to market novelties in } \\
\text { that period; computed as: share of sales with market novelties * (sales in } \\
2008 \text { / sales in 2006) }\end{array}$ \\
\hline Sales growth due to firm novelties & $\begin{array}{l}\text { Growth rate of turnover between } 2006-2008 \text { due to firm novelties in that } \\
\text { period; computed as: share of sales with firm novelties * (sales in } 2008 \text { / } \\
\text { sales in 2006) }\end{array}$ \\
\hline
\end{tabular}

\subsection{Explanatory Variables}

The literature on innovation performance has identified the following main factors that influence innovation output: (i) firms' actual innovation effort, (ii) technological capabilities describing the degree of technological accumulation and efficiency in the innovative search process, (iii) absorptive capacities, and (iv) the use of external knowledge. ${ }^{3}$ In this regard, the importance of continuous internal $R \& D$ activities as an indicator for innovative capabilities and absorptive capacities has been emphasised by many scholars. Becker and Peters (2000) for instance have shown that firms with pronounced absorptive capacities are more likely to have higher sales with new products.

\footnotetext{
${ }^{3}$ For an overview see for instance Peters (2008) and Hall and Mairesse (2006) and the references cited therein.
} 


\section{Domestic and Foreign R\&D Activities}

Our study is aimed at comparing the effect of domestic and foreign R\&D on firms' future innovation outcome and market success with innovations. We first construct two binary variables indicating German firms that solely perform R\&D activities in Germany in 2005 (firms with domestic R\&D only) and that have both R\&D laboratories in Germany and abroad (firms with domestic and foreign $R \& D) .{ }^{4}$ Note that differences between the effect of domestic and foreign $R \& D$ on innovation performance might capture differences in the access to external knowledge as well as differences in innovative capabilities and absorptive capacities that are built in the course of $R \& D$ activities. Furthermore, note that not all firms have performed $R \& D$ activities in 2005. Among the non-R\&D performing firms we further separate between firms with no innovations activities (firms without innovation activities) and firms with innovation activities but without conducting any R\&D activities (innovative firms without $R \& D$ ). The latter group reflects the well-known fact that $R \& D$ is not the only way for an enterprise to introduce new products. ${ }^{5}$ The reference category in our analysis comprises innovative firms without $R \& D$ activities in 2005.

In a second step, we further subdivide international $R \& D$ performers according to their degree of $R \& D$ internationalisation. We create three binary variables indicating the intensity of firms' foreign $R \& D$ engagement by using the number of countries in which the firms carry out R\&D activities. A firm is defined to have centralised, medium decentralised and decentralised foreign $R \& D$ activities if it performs $R \& D$ in one, two to three and more than three foreign countries, respectively. A detailed list of variable definitions is provided in Table 2.

\section{Control Variables}

In addition to dummies indicating the location of $R \& D$ activities, we include $R \& D$ intensity (R\&D expenditure per sales in 2005) and non-R\&D innovation intensity (innovation expenditure (except R\&D expenditure) per sales in 2005) to capture innovation efforts. We expect the impact on innovation performance to be positive. We model a second order polynomial to account for any non-linearities. In addition to R\&D, technological capabilities are measured by the share of high skilled employees in 2005 (Lööf and Heshmati, 2002).

\footnotetext{
${ }^{4}$ Only one firm in the sample reported to perform R\&D activities solely abroad. We therefore decided to exclude this firm from the estimation. Thus, we are not able to test the complementarity hypothesis.

${ }^{5}$ Other innovation activities include for instance the acquisition of machines and external knowledge such as patents and licenses.
} 
Table 2: Definition of Explanatory Variables

\begin{tabular}{|c|c|}
\hline Innovation activities in year 2005 & Definition \\
\hline Firms with domestic R\&D only & $\begin{array}{l}1 \text { if the firm performs intramural R\&D activities only in Germany in } \\
2005\end{array}$ \\
\hline Firms with domestic and foreign R\&D & $\begin{array}{l}1 \text { if the firm performs intramural R\&D activities in Germany and in at } \\
\text { least one R\&D laboratory abroad }\end{array}$ \\
\hline Firms without R\&D (reference group) & $\begin{array}{l}1 \text { if the firm is engaged in other innovation activities except for } \\
\text { intramural R\&D activities in } 2005 \text {, e.g. extramural R\&D activities, } \\
\text { acquisition of external knowledge or machines, design, product testing } \\
\text { and preparation. }\end{array}$ \\
\hline Firms without innovation activities & 1 if the firm is not engaged in any innovation activities in year 2005 \\
\hline Firms with centralised foreign $R \& D$ & 1 if the firm has an R\&D lab in only 1 country abroad in year 2005 \\
\hline $\begin{array}{l}\text { Firms with medium decentralised } \\
\text { foreign R\&D }\end{array}$ & 1 if the firm has R\&D labs in 2 or 3 countries abroad in year 2005 \\
\hline Firms with decentralised foreign $R \& D$ & 1 if the firm has R\&D labs in 4 or more countries abroad in year 2005 \\
\hline Control Variables related to year 2005 & Definition \\
\hline$R \& D$ intensity & R\&D expenditure per sales in year 2005 \\
\hline Non-R\&D-intensity & Innovation expenditure (except for R\&D) per sales in year 2005 \\
\hline High-skilled employees & $\begin{array}{l}\text { No. of graduated employees per total number of employees in year } \\
2005\end{array}$ \\
\hline Degree of product diversification & $\begin{array}{l}1 \text { divided by the share of sales with the most important product in year } \\
2005\end{array}$ \\
\hline National group & 1 if the firm is part of a national group \\
\hline Intern. group with German HQ & 1 if the firm is part of an international group headquartered in Germany \\
\hline Intern. group with HQ abroad & 1 if the firm is part of an international group headquartered abroad \\
\hline Exporter & 1 if the firm is exporting to markets abroad in year 2005 \\
\hline Firm size & No. of employees in year 2005 (in log) \\
\hline Firm in East Germany & 1 if the firm is located in East Germany \\
\hline \multicolumn{2}{|l|}{ Competitive Environment } \\
\hline Competition: Price & $\begin{array}{l}\text { Average importance of price as indicator of competition (at NACE } 3 \\
\text { industry level) }\end{array}$ \\
\hline Competition: Technology & $\begin{array}{l}\text { Average importance of technological advantage as indicator of } \\
\text { competition (at NACE } 3 \text { industry level) }\end{array}$ \\
\hline Industry & Industry classification is based on Legler and Frietsch (2007) \\
\hline High R\&D-intensive manufacturing & $\begin{array}{l}1 \text { if the firm belongs to high R\&D intensive manufacturing (NACE } 3 \\
\text { digit: } 233,242,244,296,300,321-323,331-333,353 \text { ) }\end{array}$ \\
\hline Medium R\&D-intensive manufacturing & $\begin{array}{l}1 \text { if the firm belongs to medium R\&D intensive manufacturing (NACE } \\
3 \text { digit: } 241,246,251,291,293-295,311,312,314-316,334,341,343 \text {, } \\
352 \text { ) }\end{array}$ \\
\hline Low R\&D-intensive manufacturing & $\begin{array}{l}1 \text { if the firm belongs to low R\&D intensive manufacturing (NACE } 3 \\
\text { digit: } 150-455 \text {, except for those industries already counted as high and } \\
\text { medium R\&D intensive manufacturing) }\end{array}$ \\
\hline Knowledge-intensive services & $\begin{array}{l}1 \text { if the firm belongs to the knowledge-intensive service sectors } \\
\text { (NACE } 3 \text { digit: } 221,523,603,611,622,623,643,651,652,660,671 \text {, } \\
701,721-726,731,732,741-744,921-925)\end{array}$ \\
\hline Other services (reference group) & $\begin{array}{l}1 \text { if the firm belongs to other service sectors (not counted as } \\
\text { knowledge-intensive service sector) }\end{array}$ \\
\hline
\end{tabular}

Besides proxies for innovation effort, technological capabilities, absorptive capacity and use of external knowledge, we control for the effect of a variety of additional variables. We 
include firm size (number of employees in 2005, in log.), firm location (dummy variable that is 1 if the firm is located in East Germany) as well as the ownership structure of the firms. That is, we distinguish whether the firm is a single entity (reference category), part of a national group, part of an international group with a German headquarter or an international group with headquarter abroad.

Nelson (1959) stressed that more diversified firms possess more opportunities for exploiting new knowledge and complementarities among their diversified activities (economies of scope in innovation) and therefore tend to be more innovative. The degree of product diversification might also indicate the level of firm knowledge and skills (Vermeulen and Barkema, 2002). It has been found to have an impact on firm performance (Chatterjee and Wernerfelt, 1991) and innovation success (Crepon et al. 1998). We include degree of product diversity in our estimations that is measured by 1 divided by the share of sales with the most important product in 2005. We furthermore include three variables that characterise the competitive environment of firms: two variables that measure whether the competition is rather price or technology driven (average importance of price and technology advantage as competitive factor, measured at the industry level, i.e. NACE 3 digit level) and a dummy variable that equals one if the firm serves international markets in 2005 (exporter). Finally, we define five industry dummies: firms belonging to high $R \& D$-intensive manufacturing, medium $R \& D$ intensive manufacturing, low $R \& D$-intensive manufacturing, knowledge-intensive services and other services (reference category). The categorisation of industries has been done following the method of Legler and Frietsch (2007) for the Federal Ministry of Education and Research to distinguish industries by their level of R\&D intensity and knowledge intensity.

\subsection{Descriptive Statistics}

After merging the 2006 and 2009 survey via the identification number of firms we retrieve a sample of 2118 innovation active firms in Germany. The descriptive statistics in Table 5 in the annex section demonstrates that $R \& D$ activities are still predominately concentrated in the national innovation environment. $28 \%$ of the sample firms conducted R\&D activities solely in their home country in $2005.11 \%$ of the firms performed R\&D activities in both Germany and foreign countries. About half of them (5\%) preferred to focus their R\&D work in one foreign country. Two or three foreign countries as sources in their innovation network are used by $3 \%$ of our sample firms and $2 \%$ of the firms are characterised by decentralised R\&D activities, i.e. they had R\&D labs in more than three countries. $19 \%$ of firms undertook innovation activities without doing R\&D in 2005 while $42 \%$ of firms had no innovation activities. 
Regarding innovation outcome, about $39 \%$ of the sample firms have introduced new products in the period between 2006 and 2008, of which 21\% launched market novelties and 34\% reported firm novelties. The average sales growth between 2006 and 2008 that is due to new products is about $13 \% .3 \%$ sales growth can be attributed to market novelties whereas firm novelties account for on average $10 \%$ sales growth in our sample. The average firm size in our sample is 4.278 which corresponds to 2488 employees. $18 \%$ of the firms are domestic groups. Multinational firms with headquarters in Germany comprise about $13 \%$ of the sample firms while $7 \%$ are headquartered abroad. The following graphs illustrate the innovation outcome and innovation success by firms' $R \& D$ efforts and the geographic location of R\&D activities. Consistently across all three types of product innovations, firms with international R\&D activities show a higher innovation outcome and given the introduction of a new product they are also more successful on the market with these products compared to firms with domestic R\&D, firms with innovations but no own $R \& D$ and firms without any innovation efforts in 2005. This is particularly evident for firm novelties, less so for market novelties. Since these differences might also capture the effect of other firm-level variables or industry effects, we carry out an econometric analysis.

Figure 1: Innovation Outcome and Innovation Success by R\&D Location

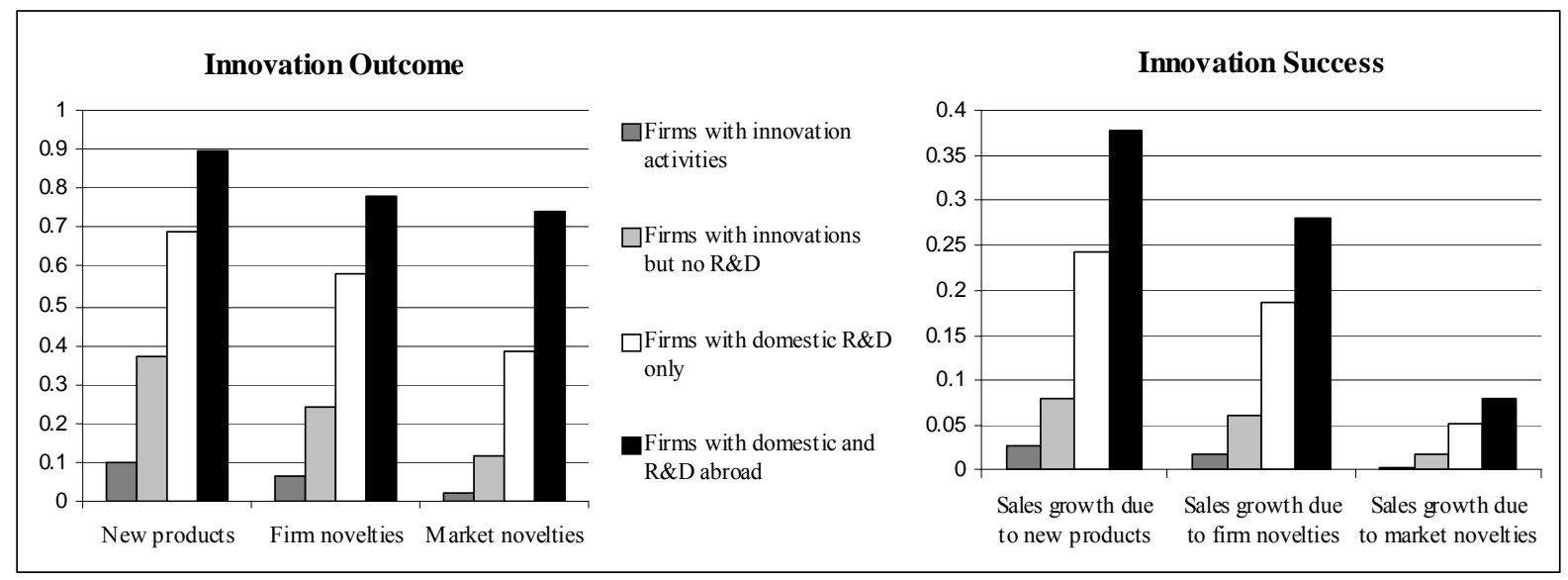

Notes: Innovation outcome is measured as the share of firm that have introduced an innovation. Innovation success is measured as the average sales growth rate due to each type of product innovation.

\subsection{Estimation Method}

To test our hypotheses we estimate three knowledge production functions (Griliches, 1986), one for each type of innovation (product innovation, market novelties, firm novelties). Since market success with innovations can only be observed if the firm has introduced an innovation, we carry out the two-step estimation procedure proposed by Heckman (1976, 1979). The selection equation estimates the effects of the explanatory variables on the likelihood to launch innovations (innovation outcome). Given the introduction of an 
innovation, the second step of the Heckman estimation is designed to estimate the impact of the explanatory variables on the growth of sales due to this innovation outcome (structural equation).

Firm size and the degree of product diversification serve as exclusion restriction. That is, we include them in the selection equation but exclude them from the structural equation. This partial overlap of the explanatory variables in the selection and structural equation ensures that the identification of parameters does not solely rely on functional form assumptions. The validity of these exclusion restrictions cannot be formally tested (see Wooldridge, 2005). However, they seemed to be justified since when including the full set of variables in both equations the two variables are significant in the selection equation but have no significant effects in the structural equation (see Table 8 and Table 7 for results of marginal effects). ${ }^{6}$

\section{Empirical Results}

Table 3 and Table 4 present the main estimation results that are the effect of international and national $R \& D$ locations as well as of different degrees of R\&D internationalization on firms' innovation outcome and innovation success. Columns 2, 4 and 6 of Tables 3 and 4 report marginal effects for a firm's likelihood to generate product innovations, firm novelties and market novelties. Corresponding innovation success is explained in columns 3, 5 and 7 . Figures show the marginal effect defined as conditional expectation.

Table 10 and Table 11 in the annex section of the paper present a robustness check of the previous estimations by eliminating firms from the sample that belong to a group with headquarter abroad.

\section{Innovation Outcome of International R\&D Activities}

The estimates show that the influence of international $R \& D$ locations is significantly positive on all innovation outcome measures. Domestic R\&D activities turned out to be conducive to innovation outcome as well. On the other hand, firms without any innovation activities in the year 2005 are significantly less (negative) likely to develop and to introduce new products in the following period 2006-2008. Having said this, our prime intention was to compare firms with domestic versus international $R \& D$ activities. We thus statistically test on equality 
between both effects. As can be gauged from the F-test, the effects of domestic R\&D and R\&D abroad are significantly different from each other. Firms with international R\&D activities exhibit a significantly higher propensity to introduce product novelties, market novelties and firm novelties. The relative difference between the marginal effect of national and international $\mathrm{R} \& \mathrm{D}$ is greatest for market novelties, which is also reflected in the test statistics (significant at the 1\% level (0.009)). The influence of international R\&D activities on new product development and firm novelties is about one third larger than the effect of domestic R\&D activities. Overall, the results strongly confirm our first hypothesis and thus the assumptions of the knowledge-based view that multiple locations offer firms attractive sources of knowledge. In addition, the results suggest that foreign subsidiaries are actually carrying out knowledge sourcing tasks and that foreign knowledge is successfully integrated into the innovation process of the whole firm.

The empirical analysis further reveals intriguing results regarding the impact of the degree of R\&D internationalisation on innovation outcomes (Table 6). On the one hand, it turns out that innovation outcome is positively related to the degree of $R \& D$ internationalisation. That is, the propensity to introduce products new to the market and new to the firm increases with the degree of decentralisation. Firms with medium decentralised foreign R\&D activities have a significantly higher likelihood to develop both market and firm novelties compared to firms with only one foreign subsidiary (centralised foreign R\&D). Comparing firms that have medium decentralised and decentralised foreign $R \& D$ activities, the results are not clear-cut. A more decentralised foreign R\&D organization does not exert an additional stimulating effect on the propensity to develop market novelties. On the other hand, it further increases the likelihood to develop firm novelties. Actually, we could not retrieve marginal effects for the effect of firms with decentralised foreign $R \& D$ on the likelihood to generate new products and firm novelties. The underlying reason is that all firms in our sample that have a high degree of $R \& D$ internationalisation ( $R \& D$ departments in more than three countries) have product innovations and firm novelties. The explanatory variable therefore predicts innovation outcome perfectly and the observations are dropped. These findings mainly support our hypothesis H3a in which we expected that innovation outcome increases with the degree of R\&D internationalisation. Comparing our results with studies examining the effect of nationally dispersed R\&D activities, we have to ascertain that our results contradict the

\footnotetext{
${ }^{6}$ In this specification the parameters of the structural equation are identified because the inverse Mills ratio is a non-linear function of the variables included in the selection equation. However, the non-linearity of the inverse Mills ratio arises from the assumption of normality in the selection equation.
} 
findings of Argyres and Silverman (2004) who found a U-shaped relationship. They are in line with Leiponen and Helfat (2010) who find that two domestic R\&D locations are most beneficial to product and process innovations as well as to any kind of innovation. 
Table 3: Effect of Domestic and International R\&D on Innovation Outcome and Innovation Success

\begin{tabular}{|c|c|c|c|c|c|c|}
\hline \multirow{3}{*}{$\begin{array}{l}\text { Prior innovation activities in } 2005 \text { (ref.: } \\
\text { firms with innovation act. except } R \& D)\end{array}$} & \multicolumn{2}{|c|}{ Product Innovation } & \multicolumn{2}{|c|}{ Market Novelties } & \multicolumn{2}{|c|}{ Firm Novelties } \\
\hline & Yes/No & \multirow[t]{2}{*}{ Sales growth } & \multirow[t]{2}{*}{ Yes/No } & \multirow[t]{2}{*}{ Sales growth } & \multirow[t]{2}{*}{ Yes/No } & \multirow[t]{2}{*}{ Sales growtl } \\
\hline & \multirow{2}{*}{$\begin{array}{l}-0.200 * * * \\
(0.021)\end{array}$} & & & & & \\
\hline Firms without innovation activities & & $\begin{array}{l}-0.070 * \\
(0.037)\end{array}$ & $\begin{array}{l}-0.131 * * * \\
(0.024)\end{array}$ & $\begin{array}{r}-0.027 \\
(0.020)\end{array}$ & $\begin{array}{l}-0.188 * * * \\
(0.023)\end{array}$ & $\begin{array}{l}-0.077 * * \\
(0.031)\end{array}$ \\
\hline Firms with domestic R\&D only & $\begin{array}{l}0.115 * * * \\
(0.022)\end{array}$ & $\begin{array}{l}0.046^{* *} \\
(0.023)\end{array}$ & $\begin{array}{l}0.079 * * * \\
(0.019)\end{array}$ & $\begin{array}{r}0.008 \\
(0.013)\end{array}$ & $\begin{array}{l}0.126^{* * * *} \\
(0.022)\end{array}$ & $\begin{array}{l}0.046^{* *} \\
(0.022)\end{array}$ \\
\hline Firms with domestic and foreign $R \& D$ & $\begin{array}{l}0.168 * * * \\
(0.035) \\
\end{array}$ & $\begin{array}{l}0.069^{* *} \\
(0.028)\end{array}$ & $\begin{array}{l}0.136 * * * \\
(0.026) \\
\end{array}$ & $\begin{array}{r}0.005 \\
(0.017)\end{array}$ & $\begin{array}{l}0.186 * * * \\
(0.034)\end{array}$ & $\begin{array}{l}0.069^{* * *} \\
(0.026)\end{array}$ \\
\hline Firm size & $\begin{array}{l}0.033^{* * *} \\
(0.005)\end{array}$ & - & $\begin{array}{l}0.031 \text { *** } \\
(0.004)\end{array}$ & - & $\begin{array}{l}0.031 \text { *** } \\
(0.005)\end{array}$ & - \\
\hline Degree of diversification & $\begin{array}{l}0.024 * * * \\
(0.008)\end{array}$ & - & $\begin{array}{r}0.008 \\
(0.006)\end{array}$ & - & $\begin{array}{r}0.003 \\
(0.005)\end{array}$ & - \\
\hline R\&D intensity & $\begin{array}{l}0.525 * * * \\
(0.190)\end{array}$ & $\begin{array}{l}0.486 * * * \\
(0.129)\end{array}$ & $\begin{array}{l}0.388 * * * \\
(0.128)\end{array}$ & $\begin{array}{l}0.384 * * * \\
(0.091)\end{array}$ & $\begin{array}{c}0.310 * \\
(0.177)\end{array}$ & $\begin{array}{c}0.185 * \\
(0.112)\end{array}$ \\
\hline Non-R\&D innov. intensity & $\begin{array}{r}-0.018 \\
(0.097)\end{array}$ & $\begin{array}{r}0.038 \\
(0.089)\end{array}$ & $\begin{array}{r}0.091 \\
(0.076)\end{array}$ & $\begin{array}{l}0.141 \text { *** } \\
(0.050)\end{array}$ & $\begin{array}{r}0.024 \\
(0.095)\end{array}$ & $\begin{array}{r}-0.115 \\
(0.080)\end{array}$ \\
\hline Share of high skilled employees & $\begin{array}{l}0.098 * * \\
(0.044)\end{array}$ & $\begin{array}{c}0.064^{*} \\
(0.038)\end{array}$ & $\begin{array}{l}0.132 * * * \\
(0.038)\end{array}$ & $\begin{array}{r}0.022 \\
(0.019)\end{array}$ & $\begin{array}{c}0.078 * \\
(0.045)\end{array}$ & $\begin{array}{r}0.053 \\
(0.034)\end{array}$ \\
\hline Exporter & $\begin{array}{l}0.057 * * * \\
(0.019)\end{array}$ & $\begin{array}{r}-0.001 \\
(0.020)\end{array}$ & $\begin{array}{l}0.062 * * * \\
(0.017)\end{array}$ & $\begin{array}{r}-0.009 \\
(0.012)\end{array}$ & $\begin{array}{l}0.044 * * \\
(0.019)\end{array}$ & $\begin{array}{r}0.012 \\
(0.017)\end{array}$ \\
\hline Firm in East Germany & $\begin{array}{r}0.003 \\
(0.018)\end{array}$ & $\begin{array}{r}0.012 \\
(0.017)\end{array}$ & $\begin{array}{l}-0.033 * * \\
(0.017)\end{array}$ & $\begin{array}{l}-0.019 * * \\
(0.009)\end{array}$ & $\begin{array}{r}0.002 \\
(0.018)\end{array}$ & $\begin{array}{c}0.026^{*} \\
(0.017)\end{array}$ \\
\hline \multicolumn{7}{|l|}{ Ownership (ref: unaffiliated firm) } \\
\hline National group & $\begin{array}{r}-0.004 \\
(0.023)\end{array}$ & $\begin{array}{r}0.027 \\
(0.019)\end{array}$ & $\begin{array}{l}-0.019 \\
(0.020)\end{array}$ & $\begin{array}{r}0.011 \\
(0.010)\end{array}$ & $\begin{array}{r}-0.006 \\
(0.023)\end{array}$ & $\begin{array}{r}0.023 \\
(0.017)\end{array}$ \\
\hline Internat. group, German HQ & $\begin{array}{c}0.054 * \\
(0.032)\end{array}$ & $\begin{array}{r}0.032 \\
(0.023)\end{array}$ & $\begin{array}{r}0.026 \\
(0.025)\end{array}$ & $\begin{array}{r}0.011 \\
(0.011)\end{array}$ & $\begin{array}{c}0.052 * \\
(0.031)\end{array}$ & $\begin{array}{r}0.031 \\
(0.021)\end{array}$ \\
\hline Internat. group, HQ abroad & $\begin{array}{r}-0.047 \\
(0.034)\end{array}$ & $\begin{array}{r}0.030 \\
(0.026)\end{array}$ & $\begin{array}{l}-0.049 * \\
(0.027)\end{array}$ & $\begin{array}{l}0.030^{* *} \\
(0.013)\end{array}$ & $\begin{array}{l}-0.085^{* *} \\
(0.034)\end{array}$ & $\begin{array}{r}0.019 \\
(0.025)\end{array}$ \\
\hline \multicolumn{7}{|l|}{ Competition } \\
\hline Price & $\begin{array}{l}-0.050 * \\
(0.026)\end{array}$ & $\begin{array}{r}-0.026 \\
(0.020)\end{array}$ & $\begin{array}{r}-0.021 \\
(0.021)\end{array}$ & $\begin{array}{r}0.008 \\
(0.010)\end{array}$ & $\begin{array}{l}-0.070 * * * \\
(0.026)\end{array}$ & $\begin{array}{l}-0.030 * \\
(0.018)\end{array}$ \\
\hline Technology & $\begin{array}{r}-0.007 \\
(0.015)\end{array}$ & $\begin{array}{r}0.022 \\
(0.014)\end{array}$ & $\begin{array}{r}-0.007 \\
(0.013)\end{array}$ & $\begin{array}{r}0.004 \\
(0.007)\end{array}$ & $\begin{array}{r}0.005 \\
(0.015)\end{array}$ & $\begin{array}{r}0.018 \\
(0.013)\end{array}$ \\
\hline \multicolumn{7}{|l|}{ Industries (ref: other services) } \\
\hline High R\&D-intensive manufacturing & $\begin{array}{l}0.127 * * * \\
(0.045)\end{array}$ & $\begin{array}{r}-0.064 \\
(0.043)\end{array}$ & $\begin{array}{c}0.072 * \\
(0.037)\end{array}$ & $\begin{array}{r}-0.002 \\
(0.019)\end{array}$ & $\begin{array}{l}0.100 * * \\
(0.044)\end{array}$ & $\begin{array}{r}-0.064 \\
(0.041)\end{array}$ \\
\hline Medium R\&D-intensive manufacturing & $\begin{array}{l}0.129 * * * \\
(0.040)\end{array}$ & $\begin{array}{r}-0.017 \\
(0.038)\end{array}$ & $\begin{array}{l}0.083 * * \\
(0.033)\end{array}$ & $\begin{array}{r}0.014 \\
(0.018)\end{array}$ & $\begin{array}{l}0.093 * * \\
(0.040)\end{array}$ & $\begin{array}{r}-0.028 \\
(0.036)\end{array}$ \\
\hline Low R\&D-intensive manufacturing & $\begin{array}{l}0.058 * * \\
(0.024)\end{array}$ & $\begin{array}{r}0.004 \\
(0.027)\end{array}$ & $\begin{array}{l}0.042 * \\
(0.024)\end{array}$ & $\begin{array}{r}0.019 \\
(0.015)\end{array}$ & $\begin{array}{l}0.064 * * \\
(0.025)\end{array}$ & $\begin{array}{r}-0.013 \\
(0.026)\end{array}$ \\
\hline Knowledge-intensive services & $\begin{array}{r}0.044 \\
(0.032) \\
\end{array}$ & $\begin{array}{r}-0.051 \\
(0.035) \\
\end{array}$ & $\begin{array}{r}-0.004 \\
(0.031) \\
\end{array}$ & $\begin{array}{r}-0.018 \\
(0.018) \\
\end{array}$ & $\begin{array}{r}0.039 \\
(0.033) \\
\end{array}$ & $\begin{array}{r}-0.036 \\
(0.032) \\
\end{array}$ \\
\hline lambda & & $\begin{array}{r}0.158 \\
(0.120) \\
\end{array}$ & & $\begin{array}{l}0.122 * * \\
(0.062) \\
\end{array}$ & & $\begin{array}{r}0.207 \\
(0.137) \\
\end{array}$ \\
\hline $\begin{array}{l}W \text { all } \\
H 0: \text { dom. } R \& D \geq \text { for. } R \& D\end{array}$ & $\begin{array}{l}0.000 * * * \\
0.054 * \\
\end{array}$ & $\begin{array}{l}0.000 * * * \\
0.112 \\
\end{array}$ & $\begin{array}{l}0.000 * * * \\
0.004 * * * \\
\end{array}$ & $\begin{array}{l}0.000 * * * \\
0.594 \\
\end{array}$ & $\begin{array}{l}0.000 * * * \\
0.022 * * \\
\end{array}$ & $\begin{array}{l}0.009 * * * \\
0.084 * \\
\end{array}$ \\
\hline $\begin{array}{l}N^{\circ} \text { of observations } \\
\text { censored obs. } \\
\text { uncensored obs. } \\
\end{array}$ & $\begin{array}{r}2118 \\
1303 \\
815 \\
\end{array}$ & & $\begin{array}{r}2118 \\
1666 \\
452 \\
\end{array}$ & & $\begin{array}{r}2118 \\
1400 \\
718 \\
\end{array}$ & \\
\hline
\end{tabular}

Notes: Marginal effects are reported. W_all is the test statistic of a Wald test on joint significance of all explanatory variables. H0: dom. $R \& D \geq$ for. $R \& D$ tests the null hypothesis that domestic $R \& D$ activities have a larger or the same effect as foreign $\mathrm{R} \& \mathrm{D}$ activities. The p-value of the F-test is reported. 
Another interesting result emerges when we compare firms with domestic R\&D and internationally dispersed $R \& D$ activities. It turns out that firms with domestic $R \& D$ and centralised foreign $R \& D$ do not significantly differ in their propensity to develop new products, neither market novelties nor firm novelties. The prior finding that firms with foreign R\&D activities benefit much more in terms of innovation outcome than domestic R\&D performers is thus mainly driven by firms with medium or decentralised international R\&D activities. The robustness check (in Table 10 and Table 11 in the annex section) of these results in which we run the same estimations but on a sample which does only include national firms approve all results for innovation outcomes of domestic and international innovating firms.

\section{Innovation Success of International R\&D activities}

We secondly investigate the effect of international R\&D activities on the innovation success measured by the sales growth due to new products, market novelties and firm novelties. Columns 3, 5 and 7 of Table 4 present average marginal effects for the expected value of the corresponding sales growth rates conditional on being selected. The estimates reveal that firms with international R\&D activities exhibit higher product innovation success than firms without $R \& D$. Compared to firms that solely perform domestic $R \& D$, they also tend to achieve higher sales growth due to new products although the difference is not statistically significant ( $\mathrm{p}$-value of a one-sided test: 0.112 ). These overall results for product innovations are mainly driven by firm novelties. On the contrary, we cannot ascertain significant results regarding the innovation success with market novelties. Given the introduction of a market novelty, firms with international $R \& D$ activities do not outperform other firms. That is, once a firm has introduced a market novelty, the location of $R \& D$ activities does not matter for innovation success. Overall, these findings do not confirm our second hypothesis in which we anticipated that firms with international $R \& D$ activities will achieve higher innovation success than firms with only domestic R\&D activities.

Investigating the impact of different degrees of international $R \& D$ decentralisation on innovation success with new products, we find a strong non-linear effect. Firms with medium decentralised R\&D abroad achieve a higher sales growth with new products than firms which conduct $\mathrm{R} \& \mathrm{D}$ at home only. The difference is statistically significant. Interestingly, they also outperform firms with highly decentralised R\&D activities. Overall, medium decentralised international R\&D turns out to be most beneficial. As before, this finding is mainly driven by firm novelties, not by market novelties. That is, given the introduction of a market novelty, the degree of decentralisation of international $R \& D$ activities does not play a role for 
innovation success. In this vein, we neither can confirm our hypothesis H4a nor H4b. However, our results are in line with Leiponen and Helfat (2010). They find a positive significant impact for firms with two domestic R\&D locations on the share of sales with product innovations. The results for prior non-innovative firms show a negative significant effect for the sales growth with firm novelties.

In comparison with the innovation outcome estimations we obtain fewer significant results in our innovation success analysis. One possible explanation can be that much more departments than $R \& D$ alone are involved until innovations are ready for the market. However, as was put forward by Singh (2008), it might also well be that foreign R\&D activities do not lead to a higher quality of innovations and therefore limit their market success.

Foreign R\&D of German subsidiary firms that belong to an international group with headquarter abroad might be quite different compared to foreign R\&D of German firms with headquarter in Germany. However, the robustness check corroborates that the positive effects of (domestic and) international R\&D activities is not driven by the former group of firms. Overall, the robustness estimates show a few less significant effects: the weak significance of domestic R\&D on sales growth due to new products as well as the weak significant effect of centralised international $R \& D$ on sales growth due to firm novelties vanishes. 
Table 4: Effect of Degree of Decentralization of International R\&D on Innovation Outcome and Innovation Success

\begin{tabular}{|c|c|c|c|c|c|c|}
\hline & \multicolumn{2}{|c|}{ Product Innovation } & \multicolumn{2}{|c|}{ Market Novelties } & \multicolumn{2}{|c|}{ Firm Novelties } \\
\hline & Yes/No & Sales growth & Yes/No & Sales growth & Yes/No & Sales growth \\
\hline \multicolumn{7}{|l|}{$\begin{array}{l}\text { Prior innovation activities in } 2005 \text { (ref.: firms with } \\
\text { innovation activities except } R \& D \text { ) }\end{array}$} \\
\hline Firms without innovation activitities & $\begin{array}{l}-0.210 * * * \\
(0.021)\end{array}$ & $\begin{array}{r}-0.065 \\
(0.040)\end{array}$ & $\begin{array}{l}-0.129 * * * \\
(0.024)\end{array}$ & $\begin{array}{r}-0.027 \\
(0.021)\end{array}$ & $\begin{array}{l}-0.203 * * * \\
(0.022)\end{array}$ & $\begin{array}{l}-0.078 * * \\
(0.033)\end{array}$ \\
\hline Firms with domestic R\&D only & $\begin{array}{l}0.100 * * * \\
(0.022)\end{array}$ & $\begin{array}{c}0.042 * \\
(0.023)\end{array}$ & $\begin{array}{l}0.079 * * * \\
(0.019)\end{array}$ & $\begin{array}{r}0.007 \\
(0.013)\end{array}$ & $\begin{array}{l}0.102 * * * \\
(0.022)\end{array}$ & $\begin{array}{l}0.041 * * \\
(0.021)\end{array}$ \\
\hline Firms with centralised foreign $R \& D$ & $\begin{array}{l}0.093 * * \\
(0.041)\end{array}$ & $\begin{array}{r}0.051 \\
(0.032)\end{array}$ & $\begin{array}{l}0.092 * * * \\
(0.030)\end{array}$ & $\begin{array}{r}0.004 \\
(0.018)\end{array}$ & $\begin{array}{l}0.097 * * \\
(0.039)\end{array}$ & $\begin{array}{c}0.049 * \\
(0.029)\end{array}$ \\
\hline Firms with medium decent. foreign $R \& D$ & $\begin{array}{l}0.352 * * * \\
(0.107)\end{array}$ & $\begin{array}{l}0.125 * * * \\
(0.036)\end{array}$ & $\begin{array}{l}0.196 * * * \\
(0.043)\end{array}$ & $\begin{array}{r}0.013 \\
(0.020)\end{array}$ & $\begin{array}{l}0.277 * * * \\
(0.072)\end{array}$ & $\begin{array}{l}0.112 * * * \\
(0.032)\end{array}$ \\
\hline Firms with decentralised foreign $R \& D$ & - & $\begin{array}{r}0.036 \\
(0.043) \\
\end{array}$ & $\begin{array}{l}0.189 * * * \\
(0.059)\end{array}$ & $\begin{array}{r}-0.010 \\
(0.025) \\
\end{array}$ & - & $\begin{array}{r}0.038 \\
(0.036) \\
\end{array}$ \\
\hline Firm size & $\begin{array}{l}0.034 * * * \\
(0.005)\end{array}$ & - & $\begin{array}{l}0.030 * * * \\
(0.004)\end{array}$ & - & $\begin{array}{l}0.033^{* * *} \\
(0.005)\end{array}$ & - \\
\hline Degree of diversification & $\begin{array}{l}0.024 * * * \\
(0.008)\end{array}$ & - & $\begin{array}{r}0.008 \\
(0.006)\end{array}$ & - & $\begin{array}{r}0.003 \\
(0.005)\end{array}$ & - \\
\hline$R \& D$ intensity & $\begin{array}{l}0.664 * * * \\
(0.193)\end{array}$ & $\begin{array}{l}0.496 * * * \\
(0.133)\end{array}$ & $\begin{array}{l}0.387 * * * \\
(0.129)\end{array}$ & $\begin{array}{l}0.397 * * * \\
(0.099)\end{array}$ & $\begin{array}{l}0.472 * * * \\
(0.178)\end{array}$ & $\begin{array}{l}0.192 * \\
(0.116)\end{array}$ \\
\hline Non-R\&D innov. intensity & $\begin{array}{r}-0.010 \\
(0.097)\end{array}$ & $\begin{array}{r}0.036 \\
(0.092)\end{array}$ & $\begin{array}{r}0.092 \\
(0.075)\end{array}$ & $\begin{array}{l}0.141 * * * \\
(0.052)\end{array}$ & $\begin{array}{r}0.033 \\
(0.095)\end{array}$ & $\begin{array}{r}-0.120 \\
(0.082)\end{array}$ \\
\hline Share of high skilled emp & $\begin{array}{l}0.105 \text { ** } \\
(0.045)\end{array}$ & $\begin{array}{r}0.060 \\
(0.040)\end{array}$ & $\begin{array}{l}0.137 \text { *** } \\
(0.038)\end{array}$ & $\begin{array}{r}0.024 \\
(0.020)\end{array}$ & $\begin{array}{c}0.086 * \\
(0.045)\end{array}$ & $\begin{array}{r}0.050 \\
(0.035)\end{array}$ \\
\hline Exporter & $\begin{array}{l}0.060 * * * \\
(0.019)\end{array}$ & $\begin{array}{r}-0.001 \\
(0.021)\end{array}$ & $\begin{array}{l}0.062 * * * \\
(0.017)\end{array}$ & $\begin{array}{r}-0.009 \\
(0.013)\end{array}$ & $\begin{array}{l}0.048 * * \\
(0.020)\end{array}$ & $\begin{array}{r}0.014 \\
(0.018)\end{array}$ \\
\hline Firm in East Germany & $\begin{array}{l}-0.001 \\
(0.018)\end{array}$ & $\begin{array}{r}0.015 \\
(0.018)\end{array}$ & $\begin{array}{l}-0.035 * * \\
(0.016)\end{array}$ & $\begin{array}{l}-0.019 * * \\
(0.010)\end{array}$ & $\begin{array}{r}-0.001 \\
(0.019)\end{array}$ & $\begin{array}{r}0.028 \\
(0.017)\end{array}$ \\
\hline Ownership (ref: unaffiliated firm) & & & & & & \\
\hline National group & $\begin{array}{r}-0.003 \\
(0.023)\end{array}$ & $\begin{array}{r}0.028 \\
(0.020)\end{array}$ & $\begin{array}{l}-0.018 \\
(0.020)\end{array}$ & $\begin{array}{r}0.012 \\
(0.010)\end{array}$ & $\begin{array}{r}-0.006 \\
(0.023)\end{array}$ & $\begin{array}{r}0.025 \\
(0.017)\end{array}$ \\
\hline Internat. group, German HQ & $\begin{array}{r}0.053 \\
(0.032)\end{array}$ & $\begin{array}{r}0.025 \\
(0.025)\end{array}$ & $\begin{array}{r}0.019 \\
(0.025)\end{array}$ & $\begin{array}{r}0.012 \\
(0.012)\end{array}$ & $\begin{array}{c}0.053 * \\
(0.032)\end{array}$ & $\begin{array}{r}0.027 \\
(0.022)\end{array}$ \\
\hline Internat. group, HQ abroad & $\begin{array}{l}-0.046 \\
(0.034)\end{array}$ & $\begin{array}{r}0.028 \\
(0.027)\end{array}$ & $\begin{array}{l}-0.050 * \\
(0.027)\end{array}$ & $\begin{array}{l}0.029 * * \\
(0.014)\end{array}$ & $\begin{array}{l}-0.080 * * \\
(0.035)\end{array}$ & $\begin{array}{r}0.018 \\
(0.025)\end{array}$ \\
\hline Competition & & & & & & \\
\hline Price & $\begin{array}{l}-0.046 * \\
(0.026)\end{array}$ & $\begin{array}{r}-0.019 \\
(0.021)\end{array}$ & $\begin{array}{r}-0.018 \\
(0.021)\end{array}$ & $\begin{array}{r}0.010 \\
(0.011)\end{array}$ & $\begin{array}{l}-0.063 * * \\
(0.026)\end{array}$ & $\begin{array}{r}-0.024 \\
(0.018)\end{array}$ \\
\hline Technology & $\begin{array}{l}-0.008 \\
(0.016)\end{array}$ & $\begin{array}{r}0.022 \\
(0.015)\end{array}$ & $\begin{array}{l}-0.005 \\
(0.013)\end{array}$ & $\begin{array}{r}0.004 \\
(0.007)\end{array}$ & $\begin{array}{r}0.004 \\
(0.016)\end{array}$ & $\begin{array}{r}0.019 \\
(0.013)\end{array}$ \\
\hline Industries (ref: other services) & & & & & & \\
\hline High R\&D-intensive manufacturing & $\begin{array}{l}0.130 \text { *** } \\
(0.045)\end{array}$ & $\begin{array}{r}-0.061 \\
(0.045)\end{array}$ & $\begin{array}{c}0.063 * \\
(0.037)\end{array}$ & $\begin{array}{r}-0.000 \\
(0.020)\end{array}$ & $\begin{array}{l}0.108 \text { ** } \\
(0.045)\end{array}$ & $\begin{array}{r}-0.060 \\
(0.042)\end{array}$ \\
\hline Medium R\&D-intensive manufacturing & $\begin{array}{l}0.130 \text { *** } \\
(0.040)\end{array}$ & $\begin{array}{l}-0.020 \\
(0.040)\end{array}$ & $\begin{array}{l}0.069 * * \\
(0.034)\end{array}$ & $\begin{array}{r}0.014 \\
(0.018)\end{array}$ & $\begin{array}{l}0.106 \text { *** } \\
(0.040)\end{array}$ & $\begin{array}{l}-0.028 \\
(0.038)\end{array}$ \\
\hline Low R\&D-intensive manufacturing & $\begin{array}{l}0.061 * * \\
(0.024)\end{array}$ & $\begin{array}{r}0.003 \\
(0.028)\end{array}$ & $\begin{array}{c}0.041 * \\
(0.024)\end{array}$ & $\begin{array}{r}0.021 \\
(0.015)\end{array}$ & $\begin{array}{l}0.070 \text { *** } \\
(0.025)\end{array}$ & $\begin{array}{l}-0.013 \\
(0.027)\end{array}$ \\
\hline Knowledge-intensive services & $\begin{array}{r}0.047 \\
(0.033) \\
\end{array}$ & $\begin{array}{r}-0.045 \\
(0.037) \\
\end{array}$ & $\begin{array}{r}-0.003 \\
(0.031) \\
\end{array}$ & $\begin{array}{r}-0.017 \\
(0.019) \\
\end{array}$ & $\begin{array}{r}0.043 \\
(0.034) \\
\end{array}$ & $\begin{array}{r}-0.028 \\
(0.033) \\
\end{array}$ \\
\hline lambda & & $\begin{array}{r}0.131 \\
(0.119) \\
\end{array}$ & & $\begin{array}{c}0.122 * \\
(0.065) \\
\end{array}$ & & $\begin{array}{r}0.195 \\
(0.131) \\
\end{array}$ \\
\hline W all & $0.000 * * *$ & $0.000 * * *$ & $0.000 * * *$ & $0.000 * * *$ & $0.000 * * *$ & $0.016^{* *}$ \\
\hline H0: dom. $R \& D>=$ cent. for. $R \& D$ & 0.578 & 0.373 & 0.298 & 0.577 & 0.548 & 0.372 \\
\hline H0: dom. $R \& D>=$ med.decent. for. $R \& D$ & $0.009 * * *$ & $0.004 * * *$ & $0.002 * * *$ & 0.321 & $0.007 * * *$ & $0.004 * * *$ \\
\hline H0: dom. R\&D>=decent. for. R\&D & - & 0.566 & $0.027 * *$ & 0.807 & - & 0.542 \\
\hline H0: cent.for.R\&D>=med.decent.for.R\&D & $0.010 * * *$ & $0.017 * *$ & $0.010 * * *$ & 0.276 & $0.009 * * *$ & $0.017 * *$ \\
\hline H0: decent. for.R\&D>=med.decent.for.R\&D & - & $0.021 * *$ & 0.460 & 0.102 & - & $0.021 * *$ \\
\hline H0: cent.for.R\&D>=decent.for.R\&D & - & 0.636 & $0.055 *$ & 0.776 & - & 0.618 \\
\hline $\begin{array}{l}\mathbf{N}^{\circ} \text { of observations } \\
\text { censored obs. } \\
\text { uncensored obs. }\end{array}$ & $\begin{array}{r}2086 \\
1298 \\
788 \\
\end{array}$ & & $\begin{array}{r}2086 \\
1659 \\
427 \\
\end{array}$ & & $\begin{array}{r}2086 \\
1393 \\
693 \\
\end{array}$ & \\
\hline
\end{tabular}

Notes: See Table 3. 


\section{Estimation Results of Control Variables}

Overall, the estimates highlight the stimulating role of innovative capabilities for innovation outcome. Both firms' $R \& D$ intensity and share of high skilled employees increase the likelihood of developing firm and market novelties. With respect to R\&D intensity, we find a non-linear effect for all kinds of innovations. ${ }^{7}$ Interestingly, we do not find a significant impact of non-R\&D innovation intensity on innovation outcome. Firms that have a higher degree of product diversification are furthermore more likely to introduce new products. Past export activities turn out to be conducive to future innovation activities as we find significant effects for all kinds of product innovation. The ownership of firms shows varying results. We do not find any significant differences between unaffiliated firms, national groups and firms belong to a multinational group with headquarter in Germany. On the contrary, international firms which are headquartered abroad are less likely to introduce firm and market novelties. Regarding the competitive environment, we find a negative effect of price competition on the introduction of firm novelties and product innovations, but no impact of technology competition on innovation.

Innovation success is driven by the firms' $R \& D$ and non- $R \& D$ innovation intensity (in case of market novelties). The results further indicate that firms belonging to a multinational group with headquarter abroad achieve higher innovation success with market novelties than other firms. Firm location, in our estimations defined as whether the firm is located in the eastern part of Germany, has an ambiguous effect. On the one hand, firms located in East Germany are less likely to introduce market novelties and they benefit less in terms of innovation success. On the other hand, they outperform West German firms regarding the sales growth due to firm novelties. Firms that operate their businesses in a competitive environment that is characterised by price competition develop not only less firm novelties they also achieve a lower sales growth rate with these new products.

\section{Conclusions}

Central objective of this paper was to examine whether international $R \& D$ activities are conducive to innovation performance. We investigated whether firms with $R \& D$ activities outside their home country benefit from these ventures in terms of a better innovation 
outcome and higher innovation success. We furthermore analysed how the degree of R\&D internationalisation, in terms of the decentralisation into various countries, moderates firms' innovativeness and innovation success. To show the benefits of a strategy to disperse $R \& D$ across foreign countries, we compared the estimation outcomes with the results of firms that solely perform R\&D within the borders of their home country and non-R\&D performing firms. Against the background of the trend to expand R\&D facilities globally, our results are useful for firms to decide whether to internationalise their R\&D activities at all as well as to extend their existing overseas R\&D locations. The literature review of this study has revealed that the few existing studies have maybe answered the question of international R\&D benefits insufficiently by relying only on patent data. This paper contributes to the literature by adding information about innovation outcomes that would not be captured by patent data, such as firm novelties and overall product innovations, as well as probably a certain share of market novelties. Moreover, we have also related the added value of international R\&D activities to the market success with innovations.

Our results show that firms that follow the trend and internationalise R\&D activities have a great potential to strengthen their innovation performance. Firms with international R\&D have a higher probability to develop product, market and firm novelties in comparison to firms that perform only domestic R\&D or non-R\&D performers. However, regarding the innovation success, the results are not as clear-cut. Given the introduction of a firm novelty, firms with international $R \& D$ centres are also more successful than non-R\&D performers and tend to be more successful than firms conducting domestic R\&D. On the contrary, the findings highlight that the location of $R \& D$ does not matter for the success of market novelties once the market novelty has been launched to the market.

In our analysis, we also investigate how the number of locations affects innovation outcome and innovation success. The econometric results disclose an inverse u-shaped relationship. That is, a moderate number of $R \& D$ locations abroad is the most beneficial strategy for generating innovation outcomes (product innovations, market and firm novelties). The same conclusion can be drawn for the sales growth due to new products and firm novelties. Another salient finding originates from this analysis: Firms that have expanded their R\&D only to one foreign country do not outperform firms with domestic R\&D. Admittedly, we cannot say whether this is a general picture or whether this is due the fact that many of these firms might

\footnotetext{
${ }^{7}$ Table 3 and 4 only reports the marginal effect of $R \& D$ intensity that is calculated based on the estimates of the linear and squared term of $R \& D$ intensity. The original coefficient estimates are provided in Table 9 in the appendix.
} 
have just recently started to internationalise their $R \& D$ and are therefore still in a learning phase. This question is put on the agenda for future research.

To sum up, international R\&D seems to ease the access to new knowledge which evidently results in a higher probability of developing innovations and therefore contributes to firms' competitiveness. Due to a lack of data, we cannot observe how knowledge is transferred and integrated within a multinational firm across countries. But based on our findings, we can conclude that on average firms with international R\&D activities have successfully installed knowledge transfer methods to channel foreign knowledge from global subsidiaries back to the home country. Our results also emphasise the perspective that international R\&D activities seem to complement existing research efforts. However, for the decision to set up R\&D facilities at foreign subsidiaries, managers should carefully choose the specific locations and limit the number to a moderate extent.

\section{References}

Archibugi, D., Immarino, S. (2002), The Globalization of Technological Innovation: Definition and Evidence, Review of International Political Economy, 9 (2), 98-122.

Argyres, N.S., Silverman, B.S. (2004), R\&D, Organization Structure, and the Development of Corporate Technological Knowledge, Strategic Management Journal, 25, 929-958.

Arora, A., Gambardella, A. (1990), Complementarity and External Linkages: The Strategies of Large Firms in Biotechnology, Journal of Industrial Economics, 38 (4), 361-379.

Arundel, A., Kabla, I. (1998), What Percentage of Innovations are Patented? Empirical Estimates for European Firms, Research Policy, 27 (2), 127-141.

Bartlett, C.A., Ghoshal, S. (1989), Managing Innovation in Transnational Corporation, in: Managing the Global Firm. Bartlett, C.A., Doz, Y., Hedlund, G. (eds.), Routledge: London, 462-476.

Becker, W., Peters, J. (2000), Technological Opportunities, Absorptive Capacities and Innovation, Volkswirtschaftliche Diskussionsreihe 195, Augsburg.

Bernard, A.B., Jensen, B. (1999), Exceptional Exporter Performance: Cause, Effect or Both?, Journal of International Economics, 47(1), 1-25.

Birkinshaw, J., Hood, N., Jonsson, S. (1998), Building Firm-Specific Advantages in Multinational Corporations: The Role of Subsidiary Initiative, Strategic Management Journal, 19(3), 221-241.

Björkman, I., Barner-Rasmussen, W., Li, L. (2004), Managing Knowledge Transfer in MNCs: The Impact of Headquarters Control Mechanisms, Journal of International Business Studies, 35 (5), 443-455.

Branstetter, L.G. (2001), Are Knowledge Spillovers International or Intranational in Scope? , Journal of International Economics; 53, 1, 53-79. 
Cassiman, B.,Veugelers, R. (2006), In Search of Complementarity in Innovation Strategy: Internal R\&D and External Knowledge Acquisition, Management Science, 52 (1), 68-82.

Cassiman, B., Veugelers, R. (2005), R\&D Cooperation between Firms and Universities. Some empirical evidence from Belgian Manufacturing, International Journal of Industrial Organisation, 23 (5-6), 355-379.

Cassiman, B., Veugelers, R. (2002), R\&D Cooperation and Spillovers: Some Empirical Evidence from Belgium, American Economic Review, 92(4), 1169-1184.

Chatterjee, S., Wernerfelt, B. (1991), The Link between resources and type of diversification: Theory and Advise, Strategic Management Journal, 12 (1), 33-48.

Chiesa, V. (1996), Managing the Internationalization of R\&D Activities, IEEE Transactions on Engineering Management, 43, 7-23.

Clerides, S.K., Lach, S., Tybout, J.R. (1998), Is Learning By Exporting Important? MicroDynamic Evidence from Colombia, Mexico, and Morocco, The Quarterly Journal of Economics, MIT Press, 113(3), 903-947.

Coase, R.H. (1937), The Nature of the Firm, Economica, 4, 16, 386-405.

Cohen, W.M., Levinthal, D.A. (1989), Innovation and Learning: The Two Faces of R\&D, The Economic Journal, 99, 569-596.

Cohen, W. M., Levinthal, D. A. (1990), Absorptive Capacity: A New Perspective on Learning and Innovation, Administrative Science Quarterly, 35(1), 128-158.

Cohen, W. M., Malerba, F. (2001), Is the Tendency to Variation a Chief Cause of Progress? Industrial \& Corporate Change, 10(3), 587-608.

Crépon, B., Duguet, E., Mairesse, J. (1998), Research Innovation and Productivity: An Econometric Analysis at the Firm Level, Economics of Innovation and New Technology, 7(2), $115-158$

Criscuolo, C., Haskel, J. E. (2003), Innovations and Productivity Growth in the UK: Evidence from CIS2 and CIS3, CeRiBA Discussion Paper, EBPF03-3(10), London.

Criscuolo, C., Haskel, J. E., Slaughter, M.J. (2010), Global Engagement and the Innovation Activities of Firms, Journal of Industrial Organization, 28, 191-202.

DeMeyer, A. (1993), Internationalising R\&D improves a Firm's Technical Learning, Research and Technology Management, 36 (Jul/Aug), 42-49.

Edler, J., Meyer-Krahmer, F., Reger, G., (2002). Changes in the Strategic Management of Technology - Results of a Global Benchmarking Study, R\&D Management, 32, 149-164.

Frost, T.S. (2001), The Geographic Sources of Foreign Subsidiaries' Innovations, Strategic Management Journal, 22, 101-123.

Frost, T.S., Birkinshaw, J.M., Ensign, P.C. (2002), Centres of Excellence in Multinational Corporations, Strategic Management Journal, 23, 997-1018.

Gassmann, O., Von Zedtwitz, M. (1999), New Concepts and Trends in International R\&D Organization, Research Policy, 28, 231-250.

Granstrand, O., Hakanson, L., Sjölander, S. (1993), Internationalization of R\&D - A Survey of Some Recent Research, Research Policy, 22, 413-430.

Grant, R. M. (1996), Toward a Knowledge-based Theory of the Firm, Strategic Management Journal, 17 (Winter Special Issue), 109-122.

Griffith, R., E. Huergo, J. Mairesse, and B. Peters (2006), Innovation and Productivity Across Four European Countries, Oxford Review of Economic Policy, 22(4), 483-498. 
Griliches, Z. (1986), Productivity, R\&D and Basic Research at the Firm Level in the 1970s', American Economic Review, 76(1), 141-154.

Griliches, Z. (1990), Patent Statistics as Economic Indicators: A Survey, Journal of Economic Literature, 28(4), 1661-1707.

Hakanson, L., Nobel, R. (1993), Foreign Research and Development in Swedish Multinationals, Research Policy, 22, (5,6), 373-396.

Hakanson, L., Nobel, R. (2001), Organizational Characteristics and Reverse Technology Transfer, Management International Review, 41 (4), 395-420.

Hall, B.H., Mairesse, J. (2006), Empirical Studies of Innovation in the Knowledge-driven Economy, Economics of Innovation \& New Technology, 15, 4/5, 289-299.

Harrison, R., Jaumandreu, J., Mairesse, J., Peters, B. (2008), Does Innovation Stimulate Employment? A Firm-Level Analysis Using Comparable Micro-Data from Four European Countries, NBER Working Paper No. 14216, Cambridge, MA.

Heckman, J.J. (1976), The Common Structure of Statistical Models of Truncation, Sample Selection and Limited Dependent Variables and a Simple Estimator for such Models, Anals of Economic and Social Measurement, 5(4), 475-492.

Heckman, J.J. (1979), Sample Selection Bias as a Specification Error, Econometrica, 47, 153161.

Hemmert, M. (2003/04), International Organization of R\&D and Technology Acquisition Performance of High-Tech Business Units, Management International Review, 43, 361-382.

Iwasa, T., Odagiri, H. (2004), Overseas R\&D, Knowledge Sourcing, and Patenting: An Empirical Study of Japanese R\&D Investment in the US, Research Policy, 33, 807-828.

Jaffe, A. B., Trajtenberg, M. (2002), Patents, Citations and Innovations: A Window on the Knowledge Economy, MIT Press, Cambridge.

Jaffe, A. B., Trajtenberg, M., Henderson, R. (1993), Geographic Localization of Knowledge Spillovers as Evidenced by Patent Citations, The Quarterly Journal of Economics, 108(3), 577-598.

Jefferson, G. H., Huamao, B., Xiaojing, G., Xiaoyun, Y. (2006), R\&D Performance in Chinese Industry, Economics of Innovation and New Technology, 15(4/5), 345-366.

Kogut, B. (1991), Joint Ventures and the Option to Expand and Acquire, Management Science, 37(1), 19-33.

Kogut, B., Zander, U. (1992) Knowledge of the Firm, Combinative Capabilities and the Replication of Technology, Organization Studies, 3, 383-397.

Kotabe, M. (1990), The Relationship Between Offshore Sourcing and Innovativeness of U.S.: An Empirical Investigation, Journal of International Business Studies, 21(4), 623-638.

Kuemmerle, W. (1997), Building Effective R\&D Capabilities Abroad, Harvard Business Review, 75, 61-70.

Legler, H., Frietsch, R. (2007), Neuabgrenzung der Wissenswirtschaft, Forschungsintensive Industrien und wissensintensive Dienstleistungen (NIW/ISI Listen 2006), Studien zum deutschen Innovationssystem Nr.22, Bundesministerium für Bildung und Forschung (BMBF).

Leiponen, A., Helfat, C. E. (2010), Location, Decentralization, and Knowledge Sources for Innovation, Organization Science, forthcoming, (doi:10.1287/orsc.1100.0526). 
Levin, R.C., Klevorick, A.K., Nelson, R.R, Winter, S.G. (1987), Appropriating the Returns from Industrial Research and Development, Bookings Papers on Economic Activity, 3, 783831.

Levinthal, D. A., March, J. G. (1993). The Myopia of Learning, Strategic Management Journal, 14 (Winter Special Issue), 95-112.

Liebeskind, J. P. (1996), Knowledge, Strategy, and the Theory of the Firm, Strategic Management Journal, 17 (Winter Special Issue), 93-107

Lööf, H., Heshmati, A. (2002), Knowledge Capital and Performance Heterogeneity: A FirmLevel Innovation Study, International Journal of Production Economics, 76, 61-85.

Love, J.H., Roper, S. (2004), The Organisation of Innovation: Collaboration, Cooperation and Multifunctional Groups in UK and German Manufacturing, Cambridge Journal of Economics, 28, 3, 379-395.

Mairesse, J., Mohnen, P. (2010), Using Innovations Surveys for Econometric Analysis, NBER Working Paper 15857, Cambridge, Mass.

Mairesse, J., Mohnen, P. (2005), The Importance of R\&D for Innovation: A Reassessment Using French Survey Data, The Journal of Technology Transfer, 30, 1-2, 183-197.

Malecki, E.J.(1980), Corporate Organization of R and D and the Location of Technological Activities, Regional Studies, 14, 219-234.

Milgrom, P., Roberts, J. (1995), Complementarities and Fit Strategy, Structure, and Organizational Change in Manufacturing, Journal of Accounting and Economics, 19(2-3), 179-208.

Minbaeva, D., Pedersen, T., Björkman, I., Fey, C.F., Park, H.J . (2003), MNC Knowledge Transfer, Subsidiary Absorptive Capacity, and HRM, Journal of International Business Studies, 34, 586-599.

Ndofor, H.A., Levitas, E. (2004), Signaling the Strategic Value of Knowledge, Journal of Management, 30 (5), 685-702.

Nelson, R.R. (1959), The Simple Economics of Basic Scientific Research, Journal of Political Economy, 67(3), 297-306.

Nobel, R., Birkinshaw, J. (1998), Innovation in Multinational Corporations: Control and Communication Patterns in International R\&D Operations, Strategic Management Journal, 19(5), 479-496.

OECD/Eurostat (2005), Oslo Manual - Guidelines for Collecting and Interpreting Innovation Data, 3rd Edition.

Pakes, A., Griliches, Z. (1984), Patents and the R\&D at the Firm Level: a First Look, in: Griliches, Z. (Ed): R\&D, Patents and Productivity, Chicago, 55-71.

Parisi, M. L., Schiantarelli, F. and A. Sembenelli (2006), Productivity, Innovation and R\&D: Micro Evidence for Italy, European Economic Review, 50(8), 2037-2061.

Pearce, R. D. (1989). The Internationalization of Research and Development by Multinational Enterprises. Basingstoke.

Pearce, R. D., Papanastassiou, M. (1996), R\&D Networks and Innovation: Decentralised Product Development in Multinational Enterprises, R\&D Management, 26 (4), 315-333.

Penner-Hahn, J., Shaver, M.J. (2005), Does International Research and Development Increase Patent Output? An Analysis of Japanese Pharmaceutical Firms, Strategic Management Journal, 26, 121-140. 
Peteraf, M.A. (1993), The Cornerstones of Competitive Advantage: A Ressource-Based View, Strategic Management Journal, 14, 179-191.

Peters, B. (2008), Innovation and Firm Performance, ZEW Economic Studies, 38, Physica, Heidelberg.

Phene, A., Almeida, P. (2008), Innovation in Multinational Subsidiaries: The Role of Knowledge Assimilation and Subsidiary Capabilities, Journal of International Business Studies, 39, 901-919.

Rammer, C. Schmiele, A. (2008), Schwerpunktbericht zur Innovationserhebung 2006, ZEW Dokumentation Nr. 08-06, Mannheim.

Scherer, F. M. (1965), Firm Size, Market Structure, Opportunity and the Output of Patented Inventions, American Economic Review, 55(5), 1097-1125.

Schmidt, T. (2005), Knowledge Flows and R\&D Co-operation: Firm-level Evidence from Germany, ZEW Discussion Paper No. 05-22, Mannheim.

Schmiedeberg, C. (2008), Complementarities of Innovation Activities: An Empirical Analysis of the German Manufacturing Sector, Research Policy, 37, 1492-1503.

Singh, J. (2008), Distributed R\&D, Cross-regional Knowledge Integration and Quality of Innovative Output, Research Policy, 37, 77-96.

Szulanski, G. (1996), Exploring internal Stickiness: Impediments to the Transfer of Best Practice Within the Firm, Strategic Management Journal, 17, 27-43.

Tilton, J.E. (1971), International Diffusion of Technology: The Case of Semiconductors, The Brookings Inst., Washington.

UNCTAD ed. (2005), World Investment Report 2005: Transnational Corporations and the Internationalisation of $R \& D$, New York and Geneva.

Vermeulen, F., Barkema, H. (2002), Pace, Rhythm, and Scope: Process Dependence in Building a Profitable Multinational Corporation, Strategic Management Journal, 23 (7), 637653.

Von Hippel, E. (1988), The Sources of Innovation, Oxford University Press, New York.

Von Zedtwitz, M., Gassmann, O., Boutellier, R. (2004), Organizing global R\&D: challenges and dilemmas, Journal of International Management, 10, 21- 49.

Von Zedtwitz, M., Gassmann, O. (2002), Market versus Technology Drive in R\&D Internationalization: Four Different Patterns of Managing Research and Development, Research Policy, 31(4), 569-588.

Williamson, O.E. (1985), The Economic Institutions of Capitalism, Free Press, New York.

Wortmann, M. (1990), Multinationals and the Internationalization of R\&D: New Developments in German Companies, Research Policy, 19, 175-183.

Wooldridge, J.M. (2005), Simple Solutions to the Initial Conditions Problem in Dynamic Nonliniear Panel Data Models with Unobserved Heterogeneity, Journal of Applied Econometrics, 20(1), 39-54. 


\section{Appendix}

Table 5: Descriptive Statistics

\begin{tabular}{|c|c|c|c|c|c|}
\hline No. & Dependent and Explanatory Variables & Mean & Std.Dev. & Min & Max \\
\hline & Firms with product innovations & 0.385 & 0.487 & 0 & 1 \\
\hline & Firms with market novelties & 0.213 & 0.410 & 0 & 1 \\
\hline & Firms with firm novelties & 0.339 & 0.473 & 0 & 1 \\
\hline & Sales growth due to new products & 0.127 & 0.338 & 0 & 7.292 \\
\hline & Sales growth due to market novelties & 0.026 & 0.125 & 0 & 4.228 \\
\hline & Sales growth due to firm novelties & 0.101 & 0.288 & 0 & 6.946 \\
\hline & Innovator without R\&D (reference group) & 0.188 & 0.391 & 0 & 1 \\
\hline 1 & Firms with innovation activities & 0.427 & 0.495 & 0 & 1 \\
\hline 2 & Firms with domestic R\&D only & 0.276 & 0.447 & 0 & 1 \\
\hline 3 & Firms with domestic and foreign $R \& D$ & 0.111 & 0.314 & 0 & 1 \\
\hline 4 & Firms with centralised foreign $R \& D$ & 0.051 & 0.221 & 0 & 1 \\
\hline 5 & Firms with medium decentralised foreign $R \& D$ & 0.030 & 0.171 & 0 & 1 \\
\hline 6 & Firms with decentralised foreign $R \& D$ & 0.016 & 0.125 & 0 & 1 \\
\hline 7 & Firm size & 4.278 & 2.220 & 0 & 12.121 \\
\hline 8 & Degree of product diversification & 1.668 & 1.496 & 1 & 50 \\
\hline 9 & High-skilled employees & 0.195 & 0.232 & 0 & 1 \\
\hline \multirow[t]{2}{*}{10} & Exporter & 0.492 & 0.500 & 0 & 1 \\
\hline & National firm, unaffiliated (reference group) & 0.621 & 0.485 & 0 & 1 \\
\hline 11 & National group & 0.179 & 0.384 & 0 & 1 \\
\hline 12 & International group with German HQ & 0.132 & 0.338 & 0 & 1 \\
\hline 13 & International group with HQ abroad & 0.068 & 0.251 & 0 & 1 \\
\hline 14 & R\&D intensity & 0.027 & 0.116 & 0 & 2.667 \\
\hline 15 & Non-R\&D intensity & 0.026 & 0.086 & 0 & 1.534 \\
\hline 16 & Firm in East Germany & 0.349 & 0.477 & 0 & 1 \\
\hline 17 & Competition: Price & 5.122 & 0.400 & 3.286 & 6 \\
\hline 18 & Competition: Technology & 3.283 & 0.710 & 1 & 5 \\
\hline 19 & Industry: High R\&D-intensive manufacturing & 0.068 & 0.253 & 0 & 1 \\
\hline 20 & Industry: Medium R\&D-intensive manufacturing & 0.108 & 0.310 & 0 & 1 \\
\hline 21 & Industry: Low R\&D-intensive manufacturing & 0.405 & 0.491 & 0 & 1 \\
\hline \multirow[t]{2}{*}{22} & Industry: Knowledge-intensive services & 0.197 & 0.398 & 0 & 1 \\
\hline & Industry: Low R\&D-intensive services (ref. group) & 0.222 & 0.416 & 0 & 1 \\
\hline
\end{tabular}


Table 6: Correlation matrix of explanatory variables (by No., see previous table)

\begin{tabular}{|c|c|c|c|c|c|c|c|c|c|c|c|c|c|c|c|c|c|c|c|c|c|c|}
\hline No. & 1 & 2 & 3 & 4 & 5 & 6 & 7 & 8 & 9 & 10 & 11 & 12 & 13 & 14 & 15 & 16 & 17 & 18 & 19 & 20 & 21 & 22 \\
\hline 1 & 1.000 & & & & & & & & & & & & & & & & & & & & & \\
\hline 2 & -0.427 & 1.000 & & & & & & & & & & & & & & & & & & & & \\
\hline 3 & -0.120 & 0.260 & 1.000 & & & & & & & & & & & & & & & & & & & \\
\hline 4 & -0.088 & 0.192 & 0.178 & 1.000 & & & & & & & & & & & & & & & & & & \\
\hline 5 & -0.288 & 0.642 & 0.070 & 0.086 & 1.000 & & & & & & & & & & & & & & & & & \\
\hline 6 & -0.225 & 0.487 & 0.181 & 0.189 & 0.272 & 1.000 & & & & & & & & & & & & & & & & \\
\hline 7 & -0.165 & 0.357 & 0.052 & 0.080 & 0.049 & 0.064 & 1.000 & & & & & & & & & & & & & & & \\
\hline 8 & -0.128 & 0.277 & 0.161 & 0.224 & 0.210 & 0.262 & 0.079 & 1.000 & & & & & & & & & & & & & & \\
\hline 9 & -0.365 & 0.806 & 0.055 & 0.062 & 0.777 & 0.581 & 0.320 & 0.187 & 1.000 & & & & & & & & & & & & & \\
\hline 10 & -0.154 & 0.464 & 0.449 & 0.294 & 0.020 & 0.028 & 0.202 & 0.262 & -0.018 & 1.000 & & & & & & & & & & & & \\
\hline 11 & 0.009 & 0.044 & 0.014 & -0.017 & 0.037 & -0.016 & 0.027 & -0.047 & 0.024 & 0.049 & 1.000 & & & & & & & & & & & \\
\hline 12 & -0.003 & 0.101 & 0.029 & -0.004 & 0.092 & 0.031 & -0.013 & 0.008 & 0.115 & 0.011 & -0.198 & 1.000 & & & & & & & & & & \\
\hline 13 & 0.062 & 0.072 & 0.033 & 0.013 & 0.048 & 0.052 & 0.020 & 0.019 & 0.070 & 0.026 & -0.069 & -0.038 & 1.000 & & & & & & & & & \\
\hline 14 & 0.079 & 0.278 & 0.094 & 0.069 & 0.201 & 0.223 & 0.086 & 0.104 & 0.267 & 0.123 & 0.076 & 0.172 & -0.026 & 1.000 & & & & & & & & \\
\hline 15 & -0.015 & 0.284 & 0.089 & 0.107 & 0.233 & 0.295 & 0.083 & 0.100 & 0.292 & 0.045 & 0.233 & 0.204 & -0.236 & 0.301 & 1.000 & & & & & & & \\
\hline 16 & -0.057 & 0.042 & 0.032 & 0.013 & 0.031 & 0.063 & 0.019 & 0.021 & 0.035 & 0.020 & 0.028 & -0.013 & -0.172 & 0.064 & 0.216 & 1.000 & & & & & & \\
\hline 17 & 0.652 & 0.176 & 0.061 & 0.056 & 0.131 & 0.143 & 0.068 & 0.090 & 0.168 & 0.053 & -0.067 & 0.120 & 0.207 & 0.329 & -0.011 & -0.112 & 1.000 & & & & & \\
\hline 18 & 0.065 & -0.102 & -0.020 & -0.025 & -0.093 & -0.078 & 0.001 & -0.028 & -0.098 & -0.001 & -0.035 & -0.090 & 0.187 & -0.152 & -0.244 & -0.238 & 0.038 & 1.000 & & & & \\
\hline 19 & 0.059 & 0.079 & 0.025 & 0.077 & 0.073 & 0.091 & 0.028 & 0.062 & 0.084 & 0.021 & -0.039 & 0.068 & 0.076 & 0.147 & 0.034 & -0.054 & 0.315 & 0.001 & 1.000 & & & \\
\hline 20 & 0.051 & 0.160 & 0.037 & 0.041 & 0.111 & 0.126 & 0.039 & 0.080 & 0.141 & 0.058 & 0.012 & 0.100 & -0.068 & 0.318 & 0.135 & 0.036 & 0.422 & -0.033 & -0.147 & 1.000 & & \\
\hline 21 & 0.067 & -0.095 & -0.027 & -0.050 & -0.074 & -0.086 & -0.002 & -0.046 & -0.083 & -0.024 & 0.036 & -0.003 & -0.340 & -0.004 & -0.003 & 0.010 & -0.220 & -0.005 & -0.285 & -0.339 & 1.000 & \\
\hline 22 & -0.039 & -0.017 & -0.021 & -0.010 & -0.019 & -0.028 & -0.026 & -0.027 & -0.019 & -0.027 & -0.062 & -0.078 & 0.513 & -0.223 & -0.148 & -0.022 & -0.069 & 0.003 & -0.186 & -0.221 & -0.430 & 1.000 \\
\hline
\end{tabular}


Table 7: Results of Heckman estimation (No exclusion restrictions) - domestic and R\&D abroad: Marginal effects

\begin{tabular}{|c|c|c|c|c|c|c|}
\hline & \multicolumn{2}{|c|}{ Product Innovation } & \multicolumn{2}{|c|}{ Market Novelties } & \multicolumn{2}{|c|}{ Firm Novelties } \\
\hline & Yes/No & Sales growth & Yes/No & Sales growth & Yes/No & Sales growth \\
\hline \multicolumn{7}{|l|}{$\begin{array}{l}\text { Prior innovation activities in } 2005 \text { (ref.: } \\
\text { firms with innov. activities except } R \& D \text { ) }\end{array}$} \\
\hline Firms without innovation activitities & $\begin{array}{l}-0.200 * * * \\
(0.021)\end{array}$ & $\begin{array}{l}-0.083 * * \\
(0.040)\end{array}$ & $\begin{array}{l}-0.131 * * * \\
(0.024)\end{array}$ & $\begin{array}{r}0.020 \\
(0.082)\end{array}$ & $\begin{array}{l}-0.188 * * * \\
(0.023)\end{array}$ & $\begin{array}{l}-0.106 * * * \\
(0.024)\end{array}$ \\
\hline Firms with domestic R\&D only & $\begin{array}{l}0.115^{* * * *} \\
(0.022)\end{array}$ & $\begin{array}{l}0.051^{* *} \\
(0.022)\end{array}$ & $\begin{array}{l}0.079 * * * \\
(0.019)\end{array}$ & $\begin{array}{r}-0.025 \\
(0.051)\end{array}$ & $\begin{array}{l}0.126^{* * * *} \\
(0.022)\end{array}$ & $\begin{array}{l}0.061 \text { *** } \\
(0.017)\end{array}$ \\
\hline Firms with domestic and foreign $R \& D$ & $\begin{array}{l}0.168^{* * *} \\
(0.035)\end{array}$ & $\begin{array}{l}0.071 * * * \\
(0.026)\end{array}$ & $\begin{array}{l}0.136 * * * \\
(0.026)\end{array}$ & $\begin{array}{r}-0.043 \\
(0.071) \\
\end{array}$ & $\begin{array}{l}0.186^{* * *} \\
(0.034)\end{array}$ & $\begin{array}{l}0.081 * * * \\
(0.020)\end{array}$ \\
\hline Firm size & $\begin{array}{l}0.033 * * * \\
(0.005)\end{array}$ & $\begin{array}{r}0.003 \\
(0.006)\end{array}$ & $\begin{array}{l}0.031 * * * \\
(0.004)\end{array}$ & $\begin{array}{c}-0.014 \\
(0.017)\end{array}$ & $\begin{array}{l}0.031 * * * \\
(0.005)\end{array}$ & $\begin{array}{c}0.007 * \\
(0.004)\end{array}$ \\
\hline Degree of diversification & $\begin{array}{l}0.024 * * * \\
(0.008)\end{array}$ & $\begin{array}{r}0.001 \\
(0.003)\end{array}$ & $\begin{array}{r}0.008 \\
(0.006)\end{array}$ & $\begin{array}{r}-0.003 \\
(0.004)\end{array}$ & $\begin{array}{r}0.003 \\
(0.005)\end{array}$ & $\begin{array}{r}0.002 \\
(0.004)\end{array}$ \\
\hline R\&D intensity & $\begin{array}{l}0.525 * * * \\
(0.190)\end{array}$ & $\begin{array}{l}0.464 \text { *** } \\
(0.124)\end{array}$ & $\begin{array}{l}0.388^{* * *} \\
(0.128)\end{array}$ & $\begin{array}{l}0.683^{* * *} \\
(0.263)\end{array}$ & $\begin{array}{c}0.310 * \\
(0.177)\end{array}$ & $\begin{array}{l}0.178 * * \\
(0.091)\end{array}$ \\
\hline Non-R\&D innov. intensity & $\begin{array}{r}-0.018 \\
(0.097)\end{array}$ & $\begin{array}{r}0.033 \\
(0.081)\end{array}$ & $\begin{array}{r}0.091 \\
(0.076)\end{array}$ & $\begin{array}{l}0.258^{* *} \\
(0.131)\end{array}$ & $\begin{array}{r}0.024 \\
(0.095)\end{array}$ & $\begin{array}{r}-0.075 \\
(0.065)\end{array}$ \\
\hline Share of high skilled employees & $\begin{array}{l}0.098^{* *} \\
(0.044)\end{array}$ & $\begin{array}{c}0.066 * \\
(0.035)\end{array}$ & $\begin{array}{l}0.132 * * * \\
(0.038)\end{array}$ & $\begin{array}{r}-0.013 \\
(0.064)\end{array}$ & $\begin{array}{c}0.078 * \\
(0.045)\end{array}$ & $\begin{array}{l}0.056^{* *} \\
(0.027)\end{array}$ \\
\hline Exporter & $\begin{array}{l}0.057^{* * *} \\
(0.019)\end{array}$ & $\begin{array}{r}0.004 \\
(0.020)\end{array}$ & $\begin{array}{l}0.062 * * * \\
(0.017)\end{array}$ & $\begin{array}{r}-0.050 \\
(0.054)\end{array}$ & $\begin{array}{l}0.044 * * \\
(0.019)\end{array}$ & $\begin{array}{r}0.018 \\
(0.013)\end{array}$ \\
\hline Firm in East Germany & $\begin{array}{r}0.003 \\
(0.018)\end{array}$ & $\begin{array}{r}0.012 \\
(0.016)\end{array}$ & $\begin{array}{l}-0.033 * * \\
(0.017)\end{array}$ & $\begin{array}{r}-0.026 \\
(0.019)\end{array}$ & $\begin{array}{r}0.002 \\
(0.018)\end{array}$ & $\begin{array}{r}0.021 \\
(0.013)\end{array}$ \\
\hline \multicolumn{7}{|l|}{ Ownership (ref: unaffiliated firm) } \\
\hline National group & $\begin{array}{r}-0.004 \\
(0.023)\end{array}$ & $\begin{array}{r}0.023 \\
(0.019)\end{array}$ & $\begin{array}{l}-0.019 \\
(0.020)\end{array}$ & $\begin{array}{r}0.030 \\
(0.027)\end{array}$ & $\begin{array}{r}-0.006 \\
(0.023)\end{array}$ & $\begin{array}{r}0.014 \\
(0.015)\end{array}$ \\
\hline Internat. group, German HQ & $\begin{array}{c}0.054 * \\
(0.032)\end{array}$ & $\begin{array}{r}0.027 \\
(0.023)\end{array}$ & $\begin{array}{r}0.026 \\
(0.025)\end{array}$ & $\begin{array}{r}0.019 \\
(0.025)\end{array}$ & $\begin{array}{c}0.052 * \\
(0.031)\end{array}$ & $\begin{array}{r}0.023 \\
(0.018)\end{array}$ \\
\hline Internat. group, HQ abroad & $\begin{array}{r}-0.047 \\
(0.034)\end{array}$ & $\begin{array}{r}0.022 \\
(0.028)\end{array}$ & $\begin{array}{l}-0.049 * \\
(0.027)\end{array}$ & $\begin{array}{r}0.083 \\
(0.060)\end{array}$ & $\begin{array}{l}-0.085 * * \\
(0.034)\end{array}$ & $\begin{array}{c}-0.005 \\
(0.024)\end{array}$ \\
\hline \multicolumn{7}{|l|}{ Competition } \\
\hline Price & $\begin{array}{l}-0.050 * \\
(0.026)\end{array}$ & $\begin{array}{r}-0.026 \\
(0.018)\end{array}$ & $\begin{array}{r}-0.021 \\
(0.021)\end{array}$ & $\begin{array}{r}0.023 \\
(0.026)\end{array}$ & $\begin{array}{l}-0.070 * * * \\
(0.026)\end{array}$ & $\begin{array}{l}-0.033 * * \\
(0.014)\end{array}$ \\
\hline Technology & $\begin{array}{r}-0.007 \\
(0.015)\end{array}$ & $\begin{array}{r}0.020 \\
(0.013)\end{array}$ & $\begin{array}{r}-0.007 \\
(0.013)\end{array}$ & $\begin{array}{r}0.010 \\
(0.015)\end{array}$ & $\begin{array}{r}0.005 \\
(0.015)\end{array}$ & $\begin{array}{r}0.013 \\
(0.010)\end{array}$ \\
\hline \multicolumn{7}{|l|}{ Industries (ref.: other services) } \\
\hline High R\&D-intensive manufacturing & $\begin{array}{l}0.127^{* * *} \\
(0.045)\end{array}$ & $\begin{array}{c}-0.049 \\
(0.047)\end{array}$ & $\begin{array}{c}0.072 * \\
(0.037)\end{array}$ & $\begin{array}{c}-0.035 \\
(0.057)\end{array}$ & $\begin{array}{l}0.100 * * \\
(0.044)\end{array}$ & $\begin{array}{r}-0.022 \\
(0.037)\end{array}$ \\
\hline Medium R\&D-intensive manufacturing & $\begin{array}{l}0.129 * * * \\
(0.040)\end{array}$ & $\begin{array}{r}-0.007 \\
(0.039)\end{array}$ & $\begin{array}{l}0.083 * * \\
(0.033)\end{array}$ & $\begin{array}{r}-0.005 \\
(0.047)\end{array}$ & $\begin{array}{l}0.093 * * \\
(0.040)\end{array}$ & $\begin{array}{r}0.000 \\
(0.030)\end{array}$ \\
\hline Low R\&D-intensive manufacturing & $\begin{array}{l}0.058 * * \\
(0.024)\end{array}$ & $\begin{array}{r}0.009 \\
(0.026)\end{array}$ & $\begin{array}{c}0.042 * \\
(0.024)\end{array}$ & $\begin{array}{r}0.018 \\
(0.031)\end{array}$ & $\begin{array}{l}0.064 * * \\
(0.025)\end{array}$ & $\begin{array}{r}0.007 \\
(0.021)\end{array}$ \\
\hline Knowledge-intensive services & $\begin{array}{r}0.044 \\
(0.032) \\
\end{array}$ & $\begin{array}{r}-0.041 \\
(0.036)\end{array}$ & $\begin{array}{r}-0.004 \\
(0.031)\end{array}$ & $\begin{array}{r}-0.040 \\
(0.042)\end{array}$ & $\begin{array}{r}0.039 \\
(0.033) \\
\end{array}$ & $\begin{array}{r}-0.013 \\
(0.026)\end{array}$ \\
\hline lambda & & $\begin{array}{r}0.241 \\
(0.201) \\
\end{array}$ & & $\begin{array}{r}-0.063 \\
(0.144) \\
\end{array}$ & & $\begin{array}{c}0.536 * \\
(0.289) \\
\end{array}$ \\
\hline W_all & $0.000 * * *$ & $0.000 * * *$ & $0.000 * * *$ & $0.000 * * *$ & $0.000 * * *$ & $0.080 *$ \\
\hline H0: dom. $R \& D>=$ for. $R \& D$ & $0.054 *$ & 0.135 & $0.004 * * *$ & 0.747 & $0.022 * *$ & $0.078 *$ \\
\hline $\begin{array}{l}\mathrm{N}^{\circ} \text { of observations } \\
\text { censored obs. } \\
\text { uncensored obs. } \\
\end{array}$ & $\begin{array}{r}2118 \\
1303 \\
815 \\
\end{array}$ & 2118 & $\begin{array}{r}2118 \\
1666 \\
452 \\
\end{array}$ & 2118 & $\begin{array}{r}2118 \\
1400 \\
718 \\
\end{array}$ & 2118 \\
\hline
\end{tabular}

Notes: See Table 3. 
Table 8: Results of Heckman estimation (No exclusion restrictions) - domestic R\&D and degree of international R\&D decentralisation: Marginal effects

\begin{tabular}{|c|c|c|c|c|c|c|}
\hline \multirow{3}{*}{\begin{tabular}{|l|} 
\\
$\begin{array}{l}\text { Prior innovation activities in } 2005 \text { (ref.: firms } \\
\text { with innovation activities except } R \& D \text { ) }\end{array}$
\end{tabular}} & \multicolumn{2}{|c|}{ Product Innovation } & \multicolumn{2}{|c|}{ Market Novelties } & \multicolumn{2}{|c|}{ Firm Novelties } \\
\hline & Yes/No & Sales growth & Yes/No & Sales growth & Yes/No & Sales growth \\
\hline & & & & & & \\
\hline Firms without innovation activitities & $\begin{array}{l}-0.210 * * * \\
(0.021)\end{array}$ & $\begin{array}{c}-0.057 \\
(0.057)\end{array}$ & $\begin{array}{l}-0.129 * * * \\
(0.024)\end{array}$ & $\begin{array}{r}0.012 \\
(0.078)\end{array}$ & $\begin{array}{l}-0.203 * * * \\
(0.022)\end{array}$ & $\begin{array}{l}-0.095 * * * \\
(0.032)\end{array}$ \\
\hline Firms with domestic R\&D only & $\begin{array}{l}0.100 * * * \\
(0.022)\end{array}$ & $\begin{array}{r}0.040 \\
(0.027)\end{array}$ & $\begin{array}{l}0.079 * * * \\
(0.019)\end{array}$ & $\begin{array}{r}-0.021 \\
(0.050)\end{array}$ & $\begin{array}{l}0.102 * * * \\
(0.022)\end{array}$ & $\begin{array}{l}0.047 * * * \\
(0.018)\end{array}$ \\
\hline Firms with centralised foreign $R \& D$ & $\begin{array}{l}0.093 * * \\
(0.041)\end{array}$ & $\begin{array}{r}0.050 \\
(0.034)\end{array}$ & $\begin{array}{l}0.092 * * * \\
(0.030)\end{array}$ & $\begin{array}{r}-0.026 \\
(0.058)\end{array}$ & $\begin{array}{l}0.097 * * \\
(0.039)\end{array}$ & $\begin{array}{c}0.050 * * \\
(0.024)\end{array}$ \\
\hline Firms with medium decent. foreign $R \& D$ & $\begin{array}{l}0.352 * * * \\
(0.107)\end{array}$ & $\begin{array}{l}0.126^{* * * *} \\
(0.038)\end{array}$ & $\begin{array}{l}0.196 \text { *** } \\
(0.043)\end{array}$ & $\begin{array}{r}-0.032 \\
(0.079)\end{array}$ & $\begin{array}{l}0.277 * * * \\
(0.072)\end{array}$ & $\begin{array}{l}0.111 * * * \\
(0.028)\end{array}$ \\
\hline Firms with decentralised foreign R\&D & $\begin{array}{r}0.000 \\
- \\
\end{array}$ & $\begin{array}{r}0.039 \\
(0.047) \\
\end{array}$ & $\begin{array}{l}0.189 * * * \\
(0.059)\end{array}$ & $\begin{array}{r}-0.067 \\
(0.092)\end{array}$ & $\begin{array}{r}0.000 \\
- \\
\end{array}$ & $\begin{array}{r}0.031 \\
(0.031) \\
\end{array}$ \\
\hline Firm size & $\begin{array}{l}0.034 * * * \\
(0.005)\end{array}$ & $\begin{array}{l}-0.002 \\
(0.008)\end{array}$ & $\begin{array}{l}0.030 * * * \\
(0.004)\end{array}$ & $\begin{array}{c}-0.012 \\
(0.016)\end{array}$ & $\begin{array}{l}0.033 * * * \\
(0.005)\end{array}$ & $\begin{array}{r}0.004 \\
(0.006)\end{array}$ \\
\hline Degree of diversification & $\begin{array}{l}0.024 * * * \\
(0.008)\end{array}$ & $\begin{array}{r}-0.000 \\
(0.004)\end{array}$ & $\begin{array}{r}0.008 \\
(0.006)\end{array}$ & $\begin{array}{l}-0.003 \\
(0.004)\end{array}$ & $\begin{array}{r}0.003 \\
(0.005)\end{array}$ & $\begin{array}{r}0.003 \\
(0.004)\end{array}$ \\
\hline R\&D intensity & $\begin{array}{l}0.664 * * * \\
(0.193)\end{array}$ & $\begin{array}{l}0.502 * * * \\
(0.141)\end{array}$ & $\begin{array}{l}0.387 * * * \\
(0.129)\end{array}$ & $\begin{array}{l}0.670 * * \\
(0.299)\end{array}$ & $\begin{array}{l}0.472 * * * \\
(0.178)\end{array}$ & $\begin{array}{l}0.201 * * \\
(0.100)\end{array}$ \\
\hline Non-R\&D innov. intensity & $\begin{array}{r}-0.010 \\
(0.097)\end{array}$ & $\begin{array}{r}0.038 \\
(0.097)\end{array}$ & $\begin{array}{r}0.092 \\
(0.075)\end{array}$ & $\begin{array}{c}0.246 * \\
(0.140)\end{array}$ & $\begin{array}{r}0.033 \\
(0.095)\end{array}$ & $\begin{array}{r}-0.093 \\
(0.077)\end{array}$ \\
\hline Share of high skilled emp & $\begin{array}{l}0.105 * * \\
(0.045)\end{array}$ & $\begin{array}{r}0.058 \\
(0.043)\end{array}$ & $\begin{array}{l}0.137 * * * \\
(0.038)\end{array}$ & $\begin{array}{l}-0.007 \\
(0.064)\end{array}$ & $\begin{array}{c}0.086 * \\
(0.045)\end{array}$ & $\begin{array}{c}0.053 * \\
(0.030)\end{array}$ \\
\hline Exporter & $\begin{array}{l}0.060 * * * \\
(0.019)\end{array}$ & $\begin{array}{r}-0.004 \\
(0.026)\end{array}$ & $\begin{array}{l}0.062 * * * \\
(0.017)\end{array}$ & $\begin{array}{r}-0.045 \\
(0.054)\end{array}$ & $\begin{array}{l}0.048 * * \\
(0.020)\end{array}$ & $\begin{array}{r}0.017 \\
(0.015)\end{array}$ \\
\hline Firm in East Germany & $\begin{array}{r}-0.001 \\
(0.018)\end{array}$ & $\begin{array}{r}0.015 \\
(0.019)\end{array}$ & $\begin{array}{l}-0.035 * * \\
(0.016)\end{array}$ & $\begin{array}{r}-0.025 \\
(0.019)\end{array}$ & $\begin{array}{l}-0.001 \\
(0.019)\end{array}$ & $\begin{array}{r}0.024 \\
(0.016)\end{array}$ \\
\hline \multicolumn{7}{|l|}{ Ownership (ref: unaffiliated firm) } \\
\hline National group & $\begin{array}{r}-0.003 \\
(0.023)\end{array}$ & $\begin{array}{r}0.031 \\
(0.023)\end{array}$ & $\begin{array}{r}-0.018 \\
(0.020)\end{array}$ & $\begin{array}{r}0.028 \\
(0.027)\end{array}$ & $\begin{array}{r}-0.006 \\
(0.023)\end{array}$ & $\begin{array}{r}0.019 \\
(0.017)\end{array}$ \\
\hline Internat. group, German HQ & $\begin{array}{r}0.053 \\
(0.032)\end{array}$ & $\begin{array}{r}0.027 \\
(0.027)\end{array}$ & $\begin{array}{r}0.019 \\
(0.025)\end{array}$ & $\begin{array}{r}0.022 \\
(0.025)\end{array}$ & $\begin{array}{c}0.053 * \\
(0.032)\end{array}$ & $\begin{array}{r}0.023 \\
(0.020)\end{array}$ \\
\hline Internat. group, HQ abroad & $\begin{array}{r}-0.046 \\
(0.034)\end{array}$ & $\begin{array}{r}0.033 \\
(0.034)\end{array}$ & $\begin{array}{l}-0.050 * \\
(0.027)\end{array}$ & $\begin{array}{r}0.075 \\
(0.061)\end{array}$ & $\begin{array}{l}-0.080 * * \\
(0.035)\end{array}$ & $\begin{array}{r}0.005 \\
(0.028)\end{array}$ \\
\hline \multicolumn{7}{|l|}{ Competition } \\
\hline Price & $\begin{array}{l}-0.046 * \\
(0.026)\end{array}$ & $\begin{array}{r}-0.019 \\
(0.022)\end{array}$ & $\begin{array}{r}-0.018 \\
(0.021)\end{array}$ & $\begin{array}{r}0.025 \\
(0.027)\end{array}$ & $\begin{array}{l}-0.063 * * \\
(0.026)\end{array}$ & $\begin{array}{r}-0.025 \\
(0.016)\end{array}$ \\
\hline Technology & $\begin{array}{r}-0.008 \\
(0.016)\end{array}$ & $\begin{array}{r}0.023 \\
(0.016)\end{array}$ & $\begin{array}{r}-0.005 \\
(0.013)\end{array}$ & $\begin{array}{r}0.009 \\
(0.015)\end{array}$ & $\begin{array}{r}0.004 \\
(0.016)\end{array}$ & $\begin{array}{r}0.015 \\
(0.012)\end{array}$ \\
\hline \multicolumn{7}{|l|}{ Industries (ref.: other services) } \\
\hline High R\&D-intensive manufacturing & $\begin{array}{l}0.130 * * * \\
(0.045)\end{array}$ & $\begin{array}{r}-0.070 \\
(0.060)\end{array}$ & $\begin{array}{c}0.063 * \\
(0.037)\end{array}$ & $\begin{array}{r}-0.023 \\
(0.051)\end{array}$ & $\begin{array}{l}0.108 * * \\
(0.045)\end{array}$ & $\begin{array}{r}-0.035 \\
(0.047)\end{array}$ \\
\hline Medium R\&D-intensive manufacturing & $\begin{array}{l}0.130 * * * \\
(0.040)\end{array}$ & $\begin{array}{r}-0.026 \\
(0.050)\end{array}$ & $\begin{array}{l}0.069 * * \\
(0.034)\end{array}$ & $\begin{array}{r}0.003 \\
(0.042)\end{array}$ & $\begin{array}{l}0.106 * * * \\
(0.040)\end{array}$ & $\begin{array}{r}-0.010 \\
(0.038)\end{array}$ \\
\hline Low R\&D-intensive manufacturing & $\begin{array}{l}0.061 * * \\
(0.024)\end{array}$ & $\begin{array}{r}-0.000 \\
(0.033)\end{array}$ & $\begin{array}{c}0.041 * \\
(0.024)\end{array}$ & $\begin{array}{r}0.023 \\
(0.029)\end{array}$ & $\begin{array}{l}0.070 * * * \\
(0.025)\end{array}$ & $\begin{array}{r}-0.000 \\
(0.027)\end{array}$ \\
\hline Knowledge-intensive services & $\begin{array}{r}0.047 \\
(0.033) \\
\end{array}$ & $\begin{array}{r}-0.051 \\
(0.045) \\
\end{array}$ & $\begin{array}{r}-0.003 \\
(0.031) \\
\end{array}$ & $\begin{array}{r}-0.034 \\
(0.041) \\
\end{array}$ & $\begin{array}{r}0.043 \\
(0.034) \\
\end{array}$ & $\begin{array}{r}-0.016 \\
(0.031) \\
\end{array}$ \\
\hline lambda & & $\begin{array}{r}0.095 \\
(0.201) \\
\end{array}$ & & $\begin{array}{r}-0.044 \\
(0.153) \\
\end{array}$ & & $\begin{array}{r}0.356 \\
(0.284) \\
\end{array}$ \\
\hline W all & $0.000 * * *$ & $0.000 * * *$ & $0.000 * * *$ & $0.000 * * *$ & $0.000 * * *$ & $0.064 *$ \\
\hline H0: dom. R\&D>=cent. for. $R \& D$ & 0.578 & 0.358 & 0.298 & 0.595 & 0.548 & 0.437 \\
\hline H0: dom. R\&D>=med.decent. for. R\&D & $0.009 * * *$ & $0.007 * * *$ & $0.002 * * *$ & 0.614 & $0.007 * * *$ & $0.006 * * *$ \\
\hline H0: dom. R\&D>=decent. for. R\&D & - & 0.515 & $0.027 * *$ & 0.818 & - & 0.694 \\
\hline H0: cent.for.R\&D>=med.decent.for.R\&D & $0.010 *$ & $0.020 * *$ & $0.010 *$ & 0.561 & $0.009 * * *$ & 0.013 \\
\hline H0: decent. for. $R \& D>=$ med.decent.for. $R \& D$ & - & 0.972 & 0.540 & 0.848 & - & 0.994 \\
\hline H0: cent.for.R\&D>=decent.for.R\&D & - & 0.602 & $0.055 *$ & 0.803 & - & 0.725 \\
\hline $\begin{array}{l}\mathbf{N}^{\circ} \text { of observations } \\
\text { censored obs. } \\
\text { uncensored obs. }\end{array}$ & $\begin{array}{r}2086 \\
1298 \\
788 \\
\end{array}$ & 2086 & $\begin{array}{r}2086 \\
1659 \\
427 \\
\end{array}$ & 2086 & $\begin{array}{r}2086 \\
1393 \\
693 \\
\end{array}$ & 2086 \\
\hline
\end{tabular}


Table 9: Coefficients of non-linear variables from Heckman estimation with exclusion restriction

\begin{tabular}{|c|c|c|c|c|c|c|}
\hline & \multicolumn{2}{|c|}{ Product Innovation } & \multicolumn{2}{|c|}{ Market Novelties } & \multicolumn{2}{|c|}{ Firm Novelties } \\
\hline & Yes/No & Sales growth & Yes/No & Sales growth & Yes/No & Sales growth \\
\hline$R \& D$ intensity & $\begin{array}{l}2.867 \text { *** } \\
(0.832)\end{array}$ & $\begin{array}{l}1.228^{* * *} \\
(0.349)\end{array}$ & $\begin{array}{l}2.387 * * * \\
(0.805)\end{array}$ & $\begin{array}{l}1.409^{* * *} \\
(0.217)\end{array}$ & $\begin{array}{l}2.062 * * * \\
(0.770)\end{array}$ & $\begin{array}{r}0.532 \\
(0.351)\end{array}$ \\
\hline R\&D intensity squared & $\begin{array}{l}-2.241 * * * \\
(0.750)\end{array}$ & $\begin{array}{l}-0.703 * * \\
(0.328)\end{array}$ & $\begin{array}{l}-1.835 * * \\
(0.735)\end{array}$ & $\begin{array}{l}-0.940 * * * \\
(0.198)\end{array}$ & $\begin{array}{l}-1.853 * * * \\
(0.714)\end{array}$ & $\begin{array}{r}-0.220 \\
(0.326)\end{array}$ \\
\hline
\end{tabular}


Table 10: Robustness check I: Marginal effects of Heckman estimations - domestic and foreign $R \& D$, firms belonging to an international group headquartered abroad excluded from the sample

\begin{tabular}{|c|c|c|c|c|c|c|}
\hline \multirow{3}{*}{$\begin{array}{l}\text { Prior innovation activities in } 2005 \text { (ref.: firms } \\
\text { with innovation activities except } R \& D \text { ) }\end{array}$} & \multicolumn{2}{|c|}{ Product Innovation } & \multicolumn{2}{|c|}{ Market Novelties } & \multicolumn{2}{|c|}{ Firm Novelties } \\
\hline & \multirow[t]{2}{*}{ Yes/No } & \multirow[t]{2}{*}{ Sales } & \multicolumn{2}{|c|}{ Yes/No Sales growth } & \multirow[t]{2}{*}{ Yes/No } & \multirow[t]{2}{*}{ Sales } \\
\hline & & & & & & \\
\hline Firms without innovation activitities & $\begin{array}{l}-0.192 * * * \\
(0.022)\end{array}$ & $\begin{array}{l}-0.070 * \\
(0.039)\end{array}$ & $\begin{array}{l}-0.115 * * * \\
(0.024)\end{array}$ & $\begin{array}{r}-0.021 \\
(0.022)\end{array}$ & $\begin{array}{l}-0.186 * * * \\
(0.023)\end{array}$ & $\begin{array}{l}-0.077 * * \\
(0.033)\end{array}$ \\
\hline Firms with domestic R\&D only & $\begin{array}{l}0.121 * * * \\
(0.023)\end{array}$ & $\begin{array}{c}0.045 * \\
(0.025)\end{array}$ & $\begin{array}{l}0.087 * * * \\
(0.020)\end{array}$ & $\begin{array}{r}0.009 \\
(0.014)\end{array}$ & $\begin{array}{l}0.127 * * * \\
(0.023)\end{array}$ & $\begin{array}{l}0.046^{* *} \\
(0.023)\end{array}$ \\
\hline Firms with domestic and foreign $R \& D$ & $\begin{array}{l}0.195^{* * *} \\
(0.039)\end{array}$ & $\begin{array}{l}0.067^{* *} \\
(0.031)\end{array}$ & $\begin{array}{l}0.155 * * * \\
(0.027)\end{array}$ & $\begin{array}{r}0.008 \\
(0.019) \\
\end{array}$ & $\begin{array}{l}0.209^{* * *} \\
(0.037)\end{array}$ & $\begin{array}{l}0.070 * * \\
(0.029)\end{array}$ \\
\hline Firm size & $\begin{array}{l}0.029 * * * \\
(0.006)\end{array}$ & - & $\begin{array}{l}0.028 * * * \\
(0.004)\end{array}$ & - & $\begin{array}{l}0.029 * * * \\
(0.005)\end{array}$ & - \\
\hline Degree of diversification & $\begin{array}{l}0.023 * * * \\
(0.009)\end{array}$ & - & $\begin{array}{r}0.006 \\
(0.005)\end{array}$ & - & $\begin{array}{r}0.002 \\
(0.005)\end{array}$ & - \\
\hline R\&D intensity & $\begin{array}{l}0.542 * * * \\
(0.200)\end{array}$ & $\begin{array}{l}0.509 * * * \\
(0.136)\end{array}$ & $\left\{\begin{array}{l}0.362 * * * \\
(0.128)\end{array}\right.$ & $\begin{array}{l}0.403^{* * *} \\
(0.108)\end{array}$ & $\begin{array}{c}0.320 * \\
(0.184)\end{array}$ & $\begin{array}{r}0.188 \\
(0.115)\end{array}$ \\
\hline Non-R\&D innov. intensity & $\begin{array}{r}-0.053 \\
(0.099)\end{array}$ & $\begin{array}{r}0.023 \\
(0.092)\end{array}$ & $\begin{array}{r}0.082 \\
(0.074)\end{array}$ & $\begin{array}{l}0.146^{* * * *} \\
(0.056)\end{array}$ & $\begin{array}{l}-0.024 \\
(0.097)\end{array}$ & $\begin{array}{r}-0.118 \\
(0.081)\end{array}$ \\
\hline Share of high skilled employees & $\begin{array}{l}0.091 * * \\
(0.045)\end{array}$ & $\begin{array}{r}0.060 \\
(0.040)\end{array}$ & $\begin{array}{l}0.110 * * * \\
(0.038)\end{array}$ & $\begin{array}{r}0.023 \\
(0.020)\end{array}$ & $\begin{array}{c}0.075 * \\
(0.045)\end{array}$ & $\begin{array}{r}0.053 \\
(0.036)\end{array}$ \\
\hline Exporter & $\begin{array}{l}0.044 * * \\
(0.020)\end{array}$ & $\begin{array}{r}-0.007 \\
(0.021)\end{array}$ & $\begin{array}{l}0.058 * * * \\
(0.017)\end{array}$ & $\begin{array}{r}-0.011 \\
(0.014)\end{array}$ & $\begin{array}{r}0.032 \\
(0.020)\end{array}$ & $\begin{array}{r}0.005 \\
(0.018)\end{array}$ \\
\hline Firm in East Germany & $\begin{array}{r}0.004 \\
(0.018)\end{array}$ & $\begin{array}{r}0.006 \\
(0.018)\end{array}$ & $\begin{array}{l}-0.030 * \\
(0.017)\end{array}$ & $\begin{array}{l}-0.023 * * \\
(0.010)\end{array}$ & $\begin{array}{r}0.010 \\
(0.019)\end{array}$ & $\begin{array}{r}0.020 \\
(0.016)\end{array}$ \\
\hline Ownership (ref: unaffiliated firm) & & & & & & \\
\hline National group & $\begin{array}{r}0.002 \\
(0.023)\end{array}$ & $\begin{array}{r}0.026 \\
(0.019)\end{array}$ & $\begin{array}{l}-0.016 \\
(0.019)\end{array}$ & $\begin{array}{r}0.010 \\
(0.010)\end{array}$ & $\begin{array}{l}-0.003 \\
(0.023)\end{array}$ & $\begin{array}{r}0.022 \\
(0.017)\end{array}$ \\
\hline Internat. group, German HQ & $\begin{array}{l}0.063 * * \\
(0.032)\end{array}$ & $\begin{array}{r}0.029 \\
(0.024)\end{array}$ & $\begin{array}{r}0.027 \\
(0.024)\end{array}$ & $\begin{array}{r}0.008 \\
(0.012)\end{array}$ & $\begin{array}{c}0.057 * \\
(0.032)\end{array}$ & $\begin{array}{r}0.027 \\
(0.022)\end{array}$ \\
\hline Competition & & & & & & \\
\hline Price & $\begin{array}{l}-0.054 * * \\
(0.026)\end{array}$ & $\begin{array}{r}-0.026 \\
(0.021)\end{array}$ & $\begin{array}{l}-0.030 \\
(0.021)\end{array}$ & $\begin{array}{r}0.011 \\
(0.011)\end{array}$ & $\begin{array}{l}-0.077 * * * \\
(0.026)\end{array}$ & $\begin{array}{l}-0.033 * \\
(0.018)\end{array}$ \\
\hline Technology & $\begin{array}{r}-0.009 \\
(0.016)\end{array}$ & $\begin{array}{r}0.021 \\
(0.015)\end{array}$ & $\begin{array}{l}-0.004 \\
(0.014)\end{array}$ & $\begin{array}{r}0.001 \\
(0.007)\end{array}$ & $\begin{array}{r}0.007 \\
(0.016)\end{array}$ & $\begin{array}{r}0.019 \\
(0.013)\end{array}$ \\
\hline Industries (ref.: other services) & & & & & & \\
\hline High R\&D-intensive manufacturing & $\begin{array}{l}0.101 * * \\
(0.047)\end{array}$ & $\begin{array}{r}-0.065 \\
(0.045)\end{array}$ & $\begin{array}{r}0.051 \\
(0.038)\end{array}$ & $\begin{array}{r}0.003 \\
(0.020)\end{array}$ & $\begin{array}{r}0.075 \\
(0.046)\end{array}$ & $\begin{array}{r}-0.066 \\
(0.042)\end{array}$ \\
\hline Medium R\&D-intensive manufacturing & $\begin{array}{l}0.146^{* * *} \\
(0.041)\end{array}$ & $\begin{array}{r}-0.016 \\
(0.041)\end{array}$ & $\begin{array}{l}0.087 * * * \\
(0.034)\end{array}$ & $\begin{array}{r}0.022 \\
(0.018)\end{array}$ & $\begin{array}{l}0.094^{* *} \\
(0.041)\end{array}$ & $\begin{array}{r}-0.031 \\
(0.038)\end{array}$ \\
\hline Low R\&D-intensive manufacturing & $\begin{array}{l}0.055 * * \\
(0.024)\end{array}$ & $\begin{array}{r}0.001 \\
(0.028)\end{array}$ & $\begin{array}{r}0.038 \\
(0.024)\end{array}$ & $\begin{array}{r}0.023 \\
(0.016)\end{array}$ & $\begin{array}{l}0.057^{* *} \\
(0.025)\end{array}$ & $\begin{array}{r}-0.018 \\
(0.027)\end{array}$ \\
\hline Knowledge-intensive services & $\begin{array}{r}0.047 \\
(0.033) \\
\end{array}$ & $\begin{array}{r}-0.054 \\
(0.038)\end{array}$ & $\begin{array}{l}-0.005 \\
(0.031)\end{array}$ & $\begin{array}{r}-0.014 \\
(0.019)\end{array}$ & $\begin{array}{r}0.032 \\
(0.034)\end{array}$ & $\begin{array}{r}-0.043 \\
(0.034)\end{array}$ \\
\hline lambda & $\begin{array}{r}0.108 \\
(0.132) \\
\end{array}$ & & $\begin{array}{c}0.121 * \\
(0.070)\end{array}$ & & $\begin{array}{r}0.191 \\
(0.150) \\
\end{array}$ & \\
\hline $\begin{array}{l}\text { W_all } \\
\text { H0: dom. R\&D >= for. R\&D }\end{array}$ & $\begin{array}{l}0.000 * * * \\
0.020 * * \\
\end{array}$ & $\begin{array}{l}0.000 * * * \\
0.140\end{array}$ & $\begin{array}{l}0.000 * * * \\
0.001 * * * \\
\end{array}$ & $\begin{array}{l}0.000 * * * \\
0.541\end{array}$ & $\begin{array}{l}0.000 * * * \\
0.007 * * * \\
\end{array}$ & $\begin{array}{l}0.032 * * \\
0.099 *\end{array}$ \\
\hline $\begin{array}{l}\mathrm{N}^{\circ} \text { of observations } \\
\text { censored obs. } \\
\text { uncensored obs. }\end{array}$ & $\begin{array}{r}1975 \\
1230 \\
715 \\
\end{array}$ & & $\begin{array}{r}1975 \\
1567 \\
408 \\
\end{array}$ & & $\begin{array}{r}1975 \\
1317 \\
658\end{array}$ & \\
\hline
\end{tabular}


Table 11: Robustness check II: Marginal effects from Heckman estimations - domestic $R \& D$ and degree of international $R \& D$ decentralisation, firms belonging to an international group headquartered abroad excluded from the sample

\begin{tabular}{|c|c|c|c|c|c|c|}
\hline \multirow{3}{*}{\begin{tabular}{l|} 
\\
\cline { 2 - 2 } \\
Prior innovation activities in 2005 (ref.: firms \\
with innovation activities except $R \& D)$
\end{tabular}} & \multicolumn{2}{|c|}{ Product Innovation } & \multicolumn{2}{|c|}{ Market Novelties } & \multicolumn{2}{|c|}{ Firm Novelties } \\
\hline & Yes/No & Sales growth & Yes/No & Sales growth & Yes/No & Sales growth \\
\hline & & & & & & \\
\hline \multirow[t]{2}{*}{ Firms without innovation activitities } & $-0.202 * * *$ & -0.062 & $-0.114 * * *$ & -0.021 & $-0.199 * * *$ & $-0.075 * *$ \\
\hline & $(0.022)$ & $(0.043)$ & $(0.024)$ & $(0.023)$ & $(0.023)$ & $(0.035)$ \\
\hline \multirow[t]{2}{*}{ Firms with domestic R\&D only } & $0.106 * * *$ & 0.040 & $0.085 * * *$ & 0.008 & $0.103 * * *$ & $0.041 *$ \\
\hline & $(0.022)$ & $(0.026)$ & $(0.019)$ & $(0.015)$ & $(0.022)$ & $(0.022)$ \\
\hline \multirow[t]{2}{*}{ Firms with centralised foreign $R \& D$} & $0.134 * * *$ & 0.044 & $0.114 * * *$ & 0.008 & $0.123 * * *$ & 0.047 \\
\hline & $(0.047)$ & $(0.037)$ & $(0.032)$ & $(0.020)$ & $(0.044)$ & $(0.032)$ \\
\hline \multirow[t]{2}{*}{ Firms with medium decent. foreign R\&D } & $0.332 * * *$ & $0.125 * * *$ & $0.218 * * *$ & 0.016 & $0.294 * * *$ & $0.115 * * *$ \\
\hline & $(0.111)$ & $(0.040)$ & $(0.047)$ & $(0.022)$ & $(0.084)$ & $(0.035)$ \\
\hline \multirow[t]{2}{*}{ Firms with decentralised foreign R\&D } & - & 0.038 & $0.210 * * *$ & -0.008 & - & 0.044 \\
\hline & & $(0.047)$ & $(0.063)$ & $(0.028)$ & & $(0.039)$ \\
\hline Firm size & $\begin{array}{l}0.030 * * * \\
(0.006)\end{array}$ & - & $\begin{array}{l}0.027^{* * * *} \\
(0.004)\end{array}$ & - & $\begin{array}{l}0.031 * * * \\
(0.005)\end{array}$ & - \\
\hline Degree of diversification & $\begin{array}{l}0.023 * * * \\
(0.009)\end{array}$ & - & $\begin{array}{r}0.006 \\
(0.005)\end{array}$ & - & $\begin{array}{r}0.001 \\
(0.005)\end{array}$ & - \\
\hline R\&D intensity & $\begin{array}{l}0.705 * * * \\
(0.203)\end{array}$ & $\begin{array}{l}0.523 * * * \\
(0.142)\end{array}$ & $\begin{array}{l}0.359 * * * \\
(0.129)\end{array}$ & $\begin{array}{l}0.417 * * * \\
(0.117)\end{array}$ & $\begin{array}{l}0.501 * * * \\
(0.184)\end{array}$ & $\begin{array}{r}0.193 \\
(0.122)\end{array}$ \\
\hline \multirow[t]{2}{*}{ Non-R\&D innov. intensity } & -0.049 & 0.023 & 0.080 & $0.146 * *$ & -0.017 & -0.124 \\
\hline & $(0.100)$ & $(0.097)$ & $(0.074)$ & $(0.058)$ & $(0.097)$ & $(0.085)$ \\
\hline \multirow[t]{2}{*}{ Share of high skilled emp } & $0.096 * *$ & 0.057 & $0.115 * * *$ & 0.024 & $0.083 *$ & 0.050 \\
\hline & $(0.046)$ & $(0.042)$ & $(0.038)$ & $(0.021)$ & $(0.046)$ & $(0.037)$ \\
\hline \multirow[t]{2}{*}{ Exporter } & $0.047 * *$ & -0.007 & $0.059 * * *$ & -0.011 & $0.035 *$ & 0.007 \\
\hline & $(0.020)$ & $(0.023)$ & $(0.017)$ & $(0.015)$ & $(0.020)$ & $(0.019)$ \\
\hline \multirow[t]{2}{*}{ Firm in East Germany } & 0.001 & 0.008 & $-0.031 *$ & $-0.023 * *$ & 0.006 & 0.022 \\
\hline & $(0.019)$ & $(0.019)$ & $(0.016)$ & $(0.011)$ & $(0.019)$ & $(0.017)$ \\
\hline \multicolumn{7}{|l|}{ Ownership (ref: unaffiliated firm) } \\
\hline \multirow[t]{2}{*}{ National group } & 0.003 & 0.027 & -0.015 & 0.011 & -0.002 & 0.023 \\
\hline & $(0.023)$ & $(0.020)$ & $(0.019)$ & $(0.010)$ & $(0.023)$ & $(0.018)$ \\
\hline \multirow[t]{2}{*}{ Internat. group, German HQ } & $0.065 * *$ & 0.019 & 0.019 & 0.009 & $0.061 *$ & 0.020 \\
\hline & $(0.032)$ & $(0.028)$ & $(0.024)$ & $(0.012)$ & $(0.032)$ & $(0.025)$ \\
\hline Competition & & & & & & \\
\hline Price & $-0.051 *$ & -0.021 & -0.028 & 0.014 & $-0.072 * * *$ & -0.027 \\
\hline & $(0.027)$ & $(0.022)$ & $(0.021)$ & $(0.012)$ & $(0.027)$ & $(0.019)$ \\
\hline Technology & -0.009 & 0.023 & -0.001 & 0.001 & 0.008 & 0.020 \\
\hline & $(0.016)$ & $(0.016)$ & $(0.014)$ & $(0.007)$ & $(0.016)$ & $(0.014)$ \\
\hline Industries & & & & & & \\
\hline High R\&D-intensive manufacturing & $0.103 * *$ & -0.065 & 0.039 & 0.006 & $0.079 *$ & -0.064 \\
\hline & $(0.047)$ & $(0.048)$ & $(0.038)$ & $(0.021)$ & $(0.047)$ & $(0.044)$ \\
\hline Medium R\&D-intensive manufacturing & $0.150 * * *$ & -0.024 & $0.075 * *$ & 0.023 & $0.103 * *$ & -0.034 \\
\hline & $(0.042)$ & $(0.044)$ & $(0.034)$ & $(0.019)$ & $(0.041)$ & $(0.040)$ \\
\hline Low R\&D-intensive manufacturing & $0.057 * *$ & -0.001 & 0.037 & 0.025 & $0.061 * *$ & -0.020 \\
\hline & $(0.025)$ & $(0.029)$ & $(0.024)$ & $(0.016)$ & $(0.025)$ & $(0.028)$ \\
\hline Knowledge-intensive services & 0.049 & -0.051 & -0.004 & -0.013 & 0.034 & -0.036 \\
\hline & $(0.033)$ & $(0.040)$ & $(0.031)$ & $(0.020)$ & $(0.034)$ & $(0.035)$ \\
\hline lambda & $\begin{array}{r}0.108 \\
(0.132)\end{array}$ & & $\begin{array}{l}0.122 * \\
(0.074)\end{array}$ & & $\begin{array}{r}0.166 \\
(0.142)\end{array}$ & \\
\hline W all & $0.000 * * *$ & $0.000 * * *$ & $0.000 * * *$ & $0.000 * * *$ & $0.000 * * *$ & $0.058 *$ \\
\hline H0: dom. R\&D>=cent. for. $R \& D$ & 0.261 & 0.436 & 0.148 & 0.492 & 0.311 & 0.405 \\
\hline H0: dom. R\&D>=med.decent. for. R\&D & $0.020 * *$ & $0.007 * * *$ & $0.001 * * *$ & 0.299 & $0.010 *$ & $0.006 * * *$ \\
\hline H0: dom. R\&D>=decent. for. R\&D & & 0.516 & $0.020 * *$ & 0.784 & & 0.471 \\
\hline H0: cent.for.R\&D>=med.decent.for.R\&D & $0.045 * *$ & $0.021 * *$ & $0.018 * *$ & 0.314 & $0.028 * *$ & $0.022 * *$ \\
\hline H0: decent. for.R\&D $>=$ med.decent.for.R\&D & & $0.033 * *$ & 0.454 & 0.106 & & $0.036 * *$ \\
\hline H0: cent.for.R\&D>=decent.for.R\&D & & 0.553 & $0.068 *$ & 0.795 & & 0.532 \\
\hline$N^{\circ}$ of observations & 1945 & & 1945 & & 1945 & 1945 \\
\hline censored obs. & 1230 & & 1560 & & 1311 & \\
\hline uncensored obs. & 715 & & 385 & & 634 & \\
\hline
\end{tabular}

